\title{
Sınıf Yönetimi Olgusunun Pedagoji, Otorite Tipleri ve Söylemsel Güç İlişkileri Bağlamında Yeniden Değerlendirilmesi
}

\section{Reconsideration of Classroom Management Phenomenon in the context of Pedagogy, Types of Authority and Discursive Power Relations}

\author{
Y1lmaz SOYSAL \\ İstanbul Aydın Üniversitesi \\ yllmazsoysal@aydin.edu.tr
}

Somayyeh RADMARD

İstanbul Aydın Üniversitesi

somayyehradmard@aydin.edu.tr

Alıntılama: Soysal, Y. \& Radmard, S. (2018). Sınıf Yönetimi Olgusunun Pedagoji, Otorite Tipleri ve Söylemsel Güç İlişkileri Bağlamında Yeniden Değerlendirilmesi. Ulusal Eğitim Akademisi Dergisi, 2(2), 59-85.

Geliş tarihi:

06 Ağustos 2018

Kabul tarihi:

26 Ekim 2018

Sorumlu yazar: Somayyeh

RADMARD

somayyehradmard@aydin.edu.tr (C) 2018 UEAD.

Bütün hakları saklıdır.

Özet: $\mathrm{Bu}$ çalışma, sınıf yönetimi olgusuna yeni ya da alternatif bir perspektif sunmayı amaçlamıştır. Sınıf yönetimi sınıfın maddi bağlamının düzenlenmesi ve öğretimsel faaliyetlerin düzenlenmesi gibi iki ana etmen tarafindan açıklanabilmektedir. Bu çalışmada öncelikle, sınıfın maddi/fiziksel çevresinin önceden düzenlenmesinin, sınıf yönetimi ile ilgili bütüncül bir açıklama getiremediği tezi tartışmaya açılmıştır. Sonrasında, öğretimsel süreçlere öğrenenlerin dâhil edilmesi ya da edilmemesinin sınıf yönetimi olgusuna yansımaları ile ilgili alternatif bir perspektif öne çıkarılmıştır. Sınıf yönetimi, bu çalışma bağlamında, öğretimsel süreçlerden kopuk bir biçimde değil, pedagojik faaliyetlerin yöneylemine bağlı ve bitişik bir biçimde ele alınmıştır. Öğretimi karakterize eden, öğretimsel/pedagojik yaklaşım türü, otorite tipleri ve değişen söylemsel güç ilişkileri sınıf yönetimi bağlamında derinlemesine açıklanmış ve örneklendirilmiştir. Bu bağlamda, öğretmen-merkezli ve öğrenen-merkezli sınıf içi uygulamaların türü, epistemik ve sosyal otorite olarak çeşitlenen ve öğretmen tarafından oluşturulan otorite tipleri ve öğretmenin belli başlı pedagojiksöylemsel hamlelerinin azlığı ya da çokluğu ile oluşan sınıf içi güç ilişkileri tanımlanıp ve incelenmiştir. Öğretmenler ve öğretmen eğitimcileri adına çeşitli önerilerde bulunulmuştur.

Anahtar kelimeler: Sınıf yönetimi, fiziksel çevre, öğretimsel perspektifler, otorite tipleri, söylemsel güç ilişkileri

Received:

06 August 2018

Accepted:

26 October 2018

Corresponding author:

Somayyeh RADMARD

somayyehradmard@aydin.edu.tr
Abstract: This study aimed to present a new or alternative perspective for the classroom management phenomenon. Classroom management can be explicated and estimated by two main factors such as regulation of the material/environmental contexts and regulation of instructional activities. In the current study, at the outset, the inadequacy of the classroom management argument as pre-adjustment of the material or physical environment surrounding classroom events and happenings came up for discussion. Then, as an alternative argument, the reflections of the exclusion or inclusion of students into instructional processes on classroom management 
(C) 2018 UEAD.

All rights reserved. phenomenon were put forward. In the context of the present study, classroom management phenomenon was not considered by separating it from instructional processes, instead, it was examined by making concrete attachments to pedagogical in-class activities with a contingent manner. The type of instructional/pedagogical approach, types of authority and changing discursive power relations that characterize in-class instruction are explained and illustrated in-depth in the context of classroom management. In this context, genres of teacher-centred and learning-centred classroom implementations, variances of authority created by the teacher as a set of epistemic and social authority, in-class discursive power relations governed by particular teacher-led discursive moves' augmentation or decrease were identified and explored. Suggestions were offered for teachers and teacher educators.

Keywords: Classroom management, physical/material environment, instructional perspectives, types of authority, discursive power relations.

\section{Giriş}

Sınıf, benzer sosyo-kültürel ve sosyo-ekonomik bağlamdan gelen, ancak bireysel farkl1l1kları olabilen öğrenenlerin olușturduğu organik bir öğrenme topluluğudur. Bu topluluğun anlamlı ve etkili bir şekilde öğrenme faaliyetleri içinde olmasını ve bunun devamlılığını sağlayan şartların ve süreçlerin icra edilmesine ise sınıf yönetimi denilebilir (Brophy, 2006; Duke, 1979; Emmer ve Sabornie, 2015; Everston ve Weinstein, 2006). Gerçek anlamı itibariyle sınıf yönetimi öğrenenleri düzene sokmak ya da disipline etmek değil (Crone ve Horner, 2003; Crone, Horner ve Hawken, 2010; Weissberg, Kumpfer ve Seligman, 2003), onların öğrenme kazanımlarına katkı sağlanmasının yollarının hem öğretmence hem de öğrenenlerce aranması ve uygulanmasıdır (Doyle, 1986; Jones, 1996).

Sınıf yönetimi kavramı, bu çalışma bağlamında, bir olgu olarak ele alınmıştır. Öncelikle olgu "bize görünen şey" (Åkerlind, 2003; 2004; 2007; 2008) olarak tanımlanabilmektedir. Bu çalışmanın başat amaçlarından biri sınıf yönetimi kavramının belirli teorik kapsamlar göz önünde bulundurarak yeniden ele alınması ya da olgusallaştırılmasıdır. Ayrıca, bu çalışmada sınıf yönetiminin sadece olgusal bir sorgusu değil, ontolojik bir müzakeresi de yapılmaktadır. Başka bir deyişle, sınıf yönetimi olgusunun "varlığı ve yokluğu" yeniden tartı̧̧aya açılmış, etkili öğretimin olması halinde sınıf yönetiminin ontolojik olarak var olma zorunluluğunun ortadan kalkabileceği tezi savunulmuştur. Dolaysıyla sınıf yönetimi araştırmacılar tarafından bir olgu olarak algılanmıştır ve kabul edilmiştir. Sınıfı yönetimi olgusu, başarılı bir öğretmen olmak için önemli unsurlardan biri olarak kabul edilmektedir (Charles, 1996; Langdon, 1996; Lewis, 1999; MacBeath, 2007;). Yaygın görüş olarak sınıf yönetiminde başarılı olan bir öğretmen genellikle iyi ögretmen özelliklerini taşımaktadır (McIntyre ve Battle, 1998; Thomas, 1998; Murphy, Delli, ve Edwards, 2004). Etkili sınıf yönetiminin bilgisine ve becerisine sahip öğretmenler, öğretim yöntemlerini (Becker ve Gersten, 1982; Nelson, Johnson, Marchand, Martell, 1996; Gopinathan ve Ho, 2000; Kim, 2000; Rajput, 2001; Tang ve $\mathrm{Wu}$, 2000) ve sınıftaki araç-gereçleri etkili olarak kullanabilmekte (Dabbagh ve Bannan-Ritland, 2005), öğretim programındaki kazanımları öğrencilerin bilgi ve becerilerini değiştirebilecek biçimde tanıyıp uygulayabilmektedir (Guskey, 1988; e.g., Brookhart ve Freeman, 1992). Öğretimin ya da öğrenmenin doğası gereği öğretmenler, öğrencilerin belli başlı becerileri kazanabilmesi noktasında bazı sınıf içi durumlarla ya da güçlüklerle karşılaşabilir. Bu güçlükler ya da durumlar arasında öğrencilerin sınıf içi etkinliklerini ve ödevlerini kontrol etme (Cheng ve Townsend, 2000; Mohandas, Meng ve Keeves, 2003), sınıftaki çalışma (öğrenme, edinme vb.) koşullarını geliştirme (Pefianco, Curtis ve Keeves, 2003; 
Peterson, 2003), öğretimi engelleyici faktörleri ortadan kaldırma gibi öğeler yer alabilir (Shechtman ve Leichtentritt 2004). Esasen öğretmen, sınıf içi süreçler adına hem olumlu durumları (öğrenme ve öğretmeyi destekleyen) yaratma ve devam ettirme hem de olumsuz durumların (öğrenme ve öğretmeyi engelleyen) en düşük düzeylerde seyretmesi noktasında çaba gösteren, düzenleyici ve denetleyici kişi olarak görev yapmaktadır (e.g., Corbett ve Wilson, 2002; Romi, Lewis ve Katz, 2009). Dolayısıyla birçok çalışmada öğrencilerin akademik başarıları ve beceri edinimleri ile sınıf yönetimi olgusu arasında ciddi bir ilişkinin olabileceğini raporlanmıştır (Baker, Clark, Maier ve Viger, 2008). Ancak sınıfta her zaman öğretimi ve öğrenmeyi destekleyen olaylar gerçekleşmemektedir. Ayrıca, öğretmenler ders için ayrılan zamanın çoğunu olumsuz öğrenci davranışlarını engelleyecek sezgisel yöntemler geliştirmeye ve bunları uygulamaya harcayabilmektedir (Rosenthal ve Jacobson 2000; Downey ve Pribesh 2004; Jussim ve Harber 2005; Kunter, Baumert ve Köller, 2007). Çoğu öğretmen adayı ya da öğretmen için öğretimsel stratejileri, yöntemler, teknikler, yaklaşımlar uygulanabilir bir hâlde iken, sınıf yönetimi olgusu ve onunla eşleşmiş stratejiler belirsiz hâldedir (Stough, L, 2006). Bir öğretmen için sınıf yönetimi olgusuna yönelik bir farkındalık geliştirmek ise etkili bir öğretim ortamının planlanması ve devam ettirilmesi için sadece ilk aşamayı ifade etmektedir. Öte yandan, öğretmenlerin mesleki eğitimleri sırasında ve sonrasında sınıf yönetimi olgusuna ait bilgilerinin, becerilerinin ve pedagojik farkındalıklarının geliştirilmesi büyük ölçüde ihmal edilmektedir (Kaliska, 2002; Alexander, 2001; Alexander, 2006).

Sınıf yönetimi olgusu temelde dört öğe tarafında karakterize edilebilir; öğretimin yönetilmesi, sınıf yönetiminde prosedürler (süreçler bütünü) ve rutin işler, sınıfın fiziksel düzeninin örgütlenmesi ve öğrenci davranışlarının yönetilmesidir (Sanford ve Emer, 1998). Benzer bir biçimde, Başar (1999) ve Gündüz (2004) sınıf yönetiminin beş boyutundan söz etmektedir; sınıf ortamının fiziksel düzeni, öğretim ortamının planlanması plan-program, sınıfta güç ilişkilerin düzenlenmesi, davranış düzenlemeleri ve süre kullanımına ilişkin etkinliklerdir.

Bu yapılar genel olarak incelendiğinde ve yeniden bir sınıflandırmaya tabi tutulduğunda, esasen sınıf yönetimi, genelleyici kategoriler olarak iki eksende incelenebilir. Bunlar;

1. Sınıfta olabilecek herhangi olumsuz bir davranışın önceden engellenmesi ya da en aza indirgenmesi için maddi-bağlamsal ya da fiziksel çevrenin düzenlenmesi,

2. Öğretimsel süreçlere öğrenenlerin dâhil edilmesi ya da edilmemesidir.

Birinci genelleyici madde, öğretim esnasında aksaklıklar olmaması için maddi bağlamın ya da sınıfın organizasyonel yapısının planlanması anlamına gelmektedir (Evertson ve Harris, 1992; Kunter, Baumert ve Köller, 2007). Örneğin deney malzemeleri öncesinde düzenlenmemiş bir laboratuvar dersinde öğrenciler, deneysel düzenekleri için malzemelerini toplarken olumsuz davranışlar sergileyebilirler. Bunların önceden öğretmen tarafından tespit edilmesi ve fiziksel çevrenin (maddi bağlam) düzenlenerek olası olumsuz davranışların en aza indirgenmesi beklenmektedir. İkinci genelleyici boyut ise öğrencilerin öğretimsel süreçlere dâhil edilmesi ya da edilmemesi ve sınıftaki olumsuz davranışların artıp-azalması arasındaki ilişkiler bütününü tanımlar. Öğrenenler, sınıftaki olaylara (entelektüel etkileşimler) dâhil oldukça ve sınıftaki olayları yönettikçe daha az olumsuz davranış gösterme eğiliminde olabilirler (Emmer ve Stough, 2001; Marzano, Marzano ve Pickering, 2003). Öte yandan, öğrenenlerin günlük kullandıkları sosyal dil ve düşünme biçimlerine aykırı ya da alternatif bir söylem öğretmen tarafından sunulduğunda ve bütün öğrenen söylemleri, ilgili ayrıksı ya da alternatif söylemin kabulleri bağlamında 
değerlendirildiğinde öğrenenlerin entelektüel etkileşimlere dâhil olma durumları azalacağından, daha çok olumsuz davranış gösterme olasılıkları artabilir (Brophy, 2006; Swinson ve Harrop, 2001; Landrum ve Kauffman, 2006). Bu bağlamda sorulması gereken en önemli soru sinıf yönetimi olgusunu karakterize eden iki esastan hangisinin öne çıkarllacağ davranışlarını hangisinin daha çok kontrol ya da tahmin edeceği sorusudur. Bu araştırmada bu sorunun cevabı ilgili alan yazının sistematik bir şekilde incelenmesi ile cevaplanmaya çalışılmıştır. Ayrıca bu araştırmada yukarıdaki bağlam gözetilerek çeşitli tezler oluşturulmuştur. Bu tezler, şu şekildedir:

\#Tez-1: Sınıfın hem maddi bağlamının düzenlenmesi hem de öğretimin öğrenenleri de kapsayacak bir biçimde gerçekleştirilmesi sınıfta uyumsuz davranış gösterilme olasılığını azaltabilir.

\#Tez-2: Sadece maddi bağlamın ya da fiziksel çevrenin önceden düzenlenmesi, sınıfta olumsuz davranışların oluşmaması için yeterince etkin olmayabilir ve öğrencilerin olası olumsuz ya da olumlu davranış gösterme durumlarını tahmin edemeyebilir.

\#Tez-3: Öğretimin öğrenenleri de kapsayacak ve onları sınıfta gerçekleşen bütün süreçlere dâhil edecek şekilde planlanması ve uygulanması, öğrencilerin olası olumsuz ya da olumlu davranış gösterme durumların ciddi derecede tahmin edebilir.

\#Tez-4: Öğretimin konu-merkezli ya da öğretmen-merkezli olması ya da öğretimin becerimerkezli ya da öğrenen-merkezli olması sınıfta oluşacak olumsuz ya da olumlu davranışların önemli bir belirleyicisidir.

\#Tez-5: Öğretmenin oluşturacağı öğretim ve sınıfta ortaya çıkması muhtemel otorite yönelimleri (epistemik otorite vs. sosyal otorite, ayrıntılı açıklanacaktır) olumlu ve olumsuz öğrenci davranışların sergilenmesini kontrol edebilen önemli faktörlerden biri olabilir.

\#Tez-6: Öğretmenin pedagojik hamlelerinin yaratacağı asimetrik ya da simetrik sınıf içi sosyalsöylemsel güç ilişkileri sınıfta oluşacak olası olumsuz ve/veya olumsuz öğrenen davranışlarının önemli bir belirleyicisi olabilir.

FİGÜR 1. Çalışmanın teorik çerçevesi*

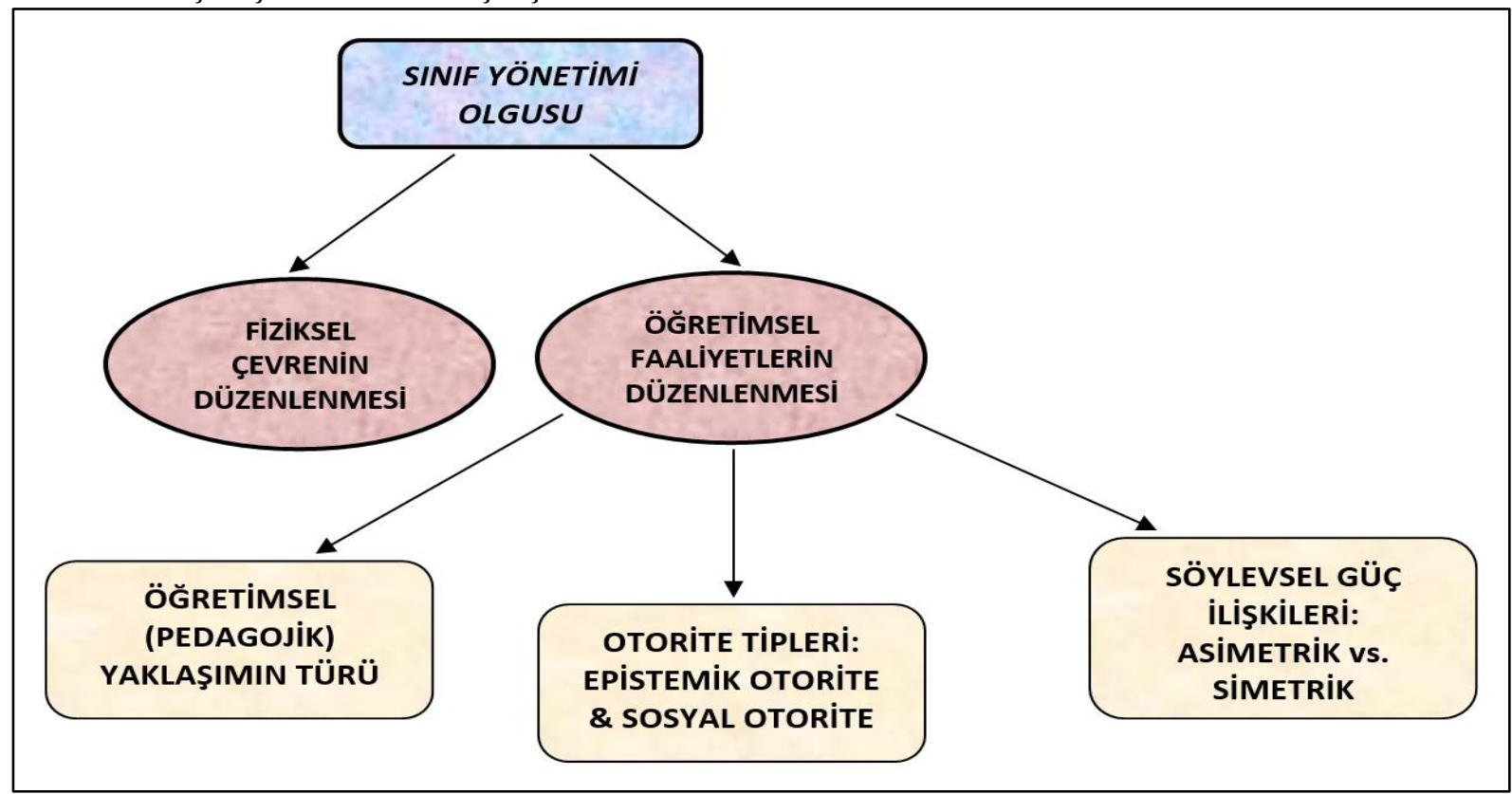

*Bu şematik gösterim araştırmacılar tarafindan yapılandırılmıştır. 
Bu tezler, esasında çalışmanın teorik çerçevesini de oluşturmaktadır. Figür 1'de çalışmanın teorik akışı ya da kabulleri görülebilir. Bu bağlamda sınıf yönetimi olgusunu açıklayan iki alt olgunun fiziksel çevrenin düzenlenmesi ve ögretimsel faaliyetlerin düzenlenmesi olduğu söylenebilir. Olumlu ve olumsuz öğrenen davranışlarında çeşitliliği asıl yaratan etmenin öğretimsel faaliyetleri karakterize eden yapılar olduğu belirtilebilir (Figür 1). Bunlar sırasıyla öğretmenmerkezli ve öğrenen-merkezli olmak üzere pedagojik yaklaşım ve uygulamaların türü, epistemik ve sosyal otorite olarak çeşitlenen ve öğretmen tarafından oluşturulan otorite tipleri ve öğretmenin belli başlı pedagojik-söylemsel hamlelerinin azlığı ya da çokluğu ile oluşan sınıf içi güç ilişkileridir (Figür 1). Çalışmanın devam eden kısımlarında özellikle "öğretimsel faaliyetlerin düzenlenmesi" olgusunu karakterize eden bu üç yapı, sınıf yönetimi bağlamında derinlemesine açıklanacak ve örneklendirilecektir.

\section{Sınıfın Maddi Bağlamının Düzenlenmesi Sınıf Yönetimi için Neden Yetersizdir?}

Sınıfın maddi bağlamı ya da fiziksel çevresi öğrenme-öğretme faaliyetlerinin meydana geldiği kurulumu tanımlar. Öğrenenler, sınıfa girdiklerinde özellikli bir pedagojik çevreye sahip olurlar. Bu fiziksel çevrenin düzenlenmesi ise hem öğrenme-öğretme hem de sınıf yönetimi olgusu ile ilgilidir ve bunları belirler. Sınıftaki sıraların düzeni, öğrencilerin oturma biçimleri, çalışılan konuya yönelik aletlerin ya da malzemelerin konumu ve dağıtımı, öğretimi zenginleştirici materyallerin öğrencilere teslim edilmesi vb. gibi sınıfın maddi bağlamını ya da fiziksel çevresini oluşturan öğelerin olumsuz davranışların ortaya çıkma durumlarını ve olasılıklarını değiştirebildiği bilinmektedir. Analitik öğeler, sınıfta kavramsal ve teknik akış için ön-belirleyici fiziksel yapılanmaları ifade eder. Bunlara ek olarak, sınıfın fiziksel ya da coğrafi konumu da sınıftaki olumlu ya da olumsuz davranışları etkileyebilir. Örneğin sınıf, fiziksel olarak cadde yanında bulunan ve fazlaca gürültüye maruz kalan bir okula aitse öğrenenler bu fiziki dezavantajdan dolayı fazlaca gürültüye maruz kalabilir ve öğretimsel süreçlere bilişsel olarak yeterince bağlanamadıklarından olumsuz davranış gösterme eğiliminde olabilirler. Ya da bir matematik sınıfında öğrenenlere öğretimsel süreçlerin zenginleştirilmesi için dağıtılan materyaller, öğretmenin istediği yönde çalışmayabilir ve bu durum, olumsuz öğrenen davranışlarına yol açabilir. Dört işlem konusunu öğretmek isteyen bir öğretmen, temel matematiksel işlemleri yapması için bir grup öğrenene gerçek para, bir grup öğrenene üzerinde para figürleri olan kâğıtlar ve bir diğer gruba da sadece çalışma kâğıtları verebilir. Süreçte gerçek para ile işlemleri yapması beklenen öğrenenler, oyun oynamaya ve paraları kendi aralarında dersin bağlamından ve içeriğinden bağımsız bir şekilde değiştirmeye başlayabilirler. Salt ve görece sıkıcı çalışma kâğıtları dağıtılmış öğrenenler, içinde oldukları süreçleri sıkıcı bulup matematiksel işlemler yerine ders dışı diyaloglarla süreci geçirebilirler. Dengeli bir şekilde hazırlanmış, üzerinde hem para figürleri olan hem de gerçek para olmayan ve öğrenenleri motive edip, harekete geçirebilecek olan simgesel paralarla matematiksel işlemleri yapmak üzere aktifleştirilmiş öğrenenler, daha çok matematiksel işlemlerle bilişsel olarak yüklü olacaklarından daha az olumsuz davranış gösterme eğiliminde olabilirler. Görüldüğü üzere fiziksel ortamın öğretimin idealize edilmiş amaçları ile uygunlaştırılmış kurgusunun garantilenmesi ve öğretimsel faaliyeti destekleyecek bir biçimde düzenlenmesi, öğretimi iyileştirip öğrenenler için öğrenme firsatları yaratabilir.

Yukarıdaki bahsi geçen durumu destekleyen çeşitli tezler yer almaktadır. Örneğin sınıfın fiziki kurulumu içinde yer alan öğrencilerin sayısı sınıf yönetimini olumsuz etkileyebilir. Kalabalık sınıflarda daha çok bilgi transferini karakterize eden öğretimsel stratejilerin benimsenmesi gerekirken, daha az mevcutlu sınıflarda ise bireysel öğretimsel yaklaşımlar tercih edilebilir. Hatta 
bazı çalışmalar (Jones ve Jones, 1984) sınıf mevcudu ile sınıf başarısı arasındaki ilişkiyi gözden geçirmiş, öğretmenin bu olumlu ya da olumsuz sonuçlanacak ilişkiyi kontrol etmesi için belirli önlemleri alması gereğini raporlanmıştır. Kısaca, yeterli sayıda öğrenci mevcudu sözde daha iyi öğrenme çıktılarını, kalabalık öğrenci grupları ise daha düşük düzeyli öğrenme çıktılarına eşlik etmektedir.

Ancak bu tipte, tek yönlü argümanalar, artık sınıf yönetimi gibi pedagoji yüklü bir kavramı açıklama, anlamlandırma ve tahmin etme noktasında oldukça yetersiz kalabilmektedir. Esasen, örneğin sınıfın üyelerinin yerleşim düzeni, sadece sınıfın maddi kurulumunu içeren öğelere işaret etmektedir, ancak öğretimin ve öğrenmenin niteliğine ve akışına vurgu yap(a)mamaktadır. Bu durumun ciddi örneklerinden biri söylem analisti Christine Chin'in (2007) oldukça kalabalık fen sınıflarında öğretmenlerin yaptığı uygulamaları değerlendirmesinden çıkan sonuçlarda kendini göstermektedir. Esas itibariyle, uluslararası çapta, öğretimin nasıllığının, niteliğinin ve felsefesinin hem doğu hem de batının pedagoji paradigmalarından etkilendiği ifade edilmektedir. Batı paradigması daha çok küçük grupların, öğrenen-merkezli ve işbirlikli sınıf içi çalışmalarını desteklerken, doğu paradigması daha çok kalabalık sınıfların olabileceği sınıf düzenlerini ya da öğretimsel stratejileri göz önünde bulundurmaktadır. Öğretmen artık sınıfı değil ya da bireyleri değil ya da sınıfin maddi kurulumu değil, öğretimi ve öğrenmeyi düşünen ve bunu yöneten kişi olarak nitelendirilmekte (Chin, 2007), öğretmen olgusu artık "koç”, "orkestra şefi”,, "pedagoji virtüözü" gibi kavramlarla anılmaktadır (Ko ve Marton, 2004). Ötesinde, değişen ve hızla genişleyen bir dünya eğitim düzeninde ve eğitime artan taleple, artık küçük mevcutlu sınıfların nasıl yönetileceği üzerine düşünülmektense, daha geniş çaplı kitlelerin, belirli bir amaç uğruna nasıl bir kurallar silsilesi işleterek profesyonel bir öğrenme topluluğuna dönüştüğü araştırma temelli bir biçimde tartışmaya açılmıştır (Lave ve Wenger, 1991). Dolayısıyla, sınıf yönetimi pedagojik bir olgu olarak, sıkıştırılmış konvansiyonel ve tipik kavramlarla ve açıklama sistemleri ile değil, bu çalışmada da amaçlandığı üzere, daha aşkın açıklama tarzları (ör., sınıf söylemi, otorite, öğretimsel nitelik) ile ele alınmalıdır.

Son tahlilde, kurgulanan fiziksel sınıf çevresi öğretimsel faaliyetlerin pedagojik içeriğinden, biçiminden ve eğilimlerinden oldukça fazla etkilenebilmektedir. Başka bir deyişle öğretimin maddi bağlamı, öğretimsel faaliyetleri gerçekleştiren öğretmenin pedagojik inanç sistemleri, öğretmeye ve öğrenmeye yüklediği anlam ve bu inanç ve algıların sınıf içine nasıl yansıtıldığı olgusu tarafından çevrelenmekte ve düzenlemektedir. Dolayısıyla sınıfın olumsuz davranışları önleyecek ya da azaltacak maddi bağlamı, sınıf yönetiminin iyileştirilmesi için önem arz eder, ancak olgunun bütününü açıklamaz ya da çok küçük bir kısmını açıklar. Bu nedenle, bu çalışmada maddi bağlam, diğer tamamlayıcı pedagojik faktörlerle birlikte ele alınmıştır ve bu faktörler devam eden kısımlarda kavramsal olarak açıklanmış ve örneklendirilmiştir.

\section{Sınıf Yönetiminin Ö̆̆retimsel (Pedagojik) Perspektiflere Zorunlu Bağlılı̆̆l}

Etkili sınıf yönetimi için nitelikli bir öğretimsel sürecin planlanması ve uygulanması öğrenme felsefelerine ve teorilerine bağlı kalarak argümanlar geliştirmeyi zorunlu kılar (Cheng, 2005). Öğrenme ve öğretmenin felsefesi ve türetilen teorileri değiştikçe öğretmen eğitimcilerinin ve öğretmenlerin sahip olduğu pedagojik kavramsallaştırmalarda zorunlu bir değişim göstermektedir. Bu bağlamda, değişen öğrenme teorileri kapsamında öne çıkan en önemli kavramlardan biri ögretmenlerin ögrenmeye ve ögretmeye yönelik zaman içinde geliştirdikleri pedagojik inanç sistemleridir (Pajares, 1992; Richardson, 1996; Wall, 2016). Başka bir deyişle 
öğretmenlerin öğrenme ile ilgili alg1, bilgi ve düşünsel sistemleri değiştikçe ve geliştikçe sınıf yönetimine yönelik geliştirdikleri ilkeleri de bunlara göre radikal bir değişim ve gelişim göstermiştir (Cheng ve Tam, 2007; Cheng ve Mok, 2008). Bir öğretmen genel itibariyle iki türlü, birbirini çoğunlukla dıştalayan bir pedagojik inanç sistemine sahip olup, sınıf içinde bu şekilde davranabilir (Soysal ve Radmard, 2018). Bunlar "öğretmen-merkezli inanç sistemi” ve "öğrenenmerkezli inanç sistemidir” (Bloom, Perlmutter ve Burrell, 1999). Öğretmen-merkezli bir pedagojik alg1 ve inanca sahip olan öğretmen, bilgilerin daha çok bilenden daha az bilene doğru aktarıldı̆̆ ve öğrenmenin ya da öğretmenin bu biçimde gerçekleştiği kanısına sahiptir (Becker ve Riel, 2000; Meirink vd., 2009). Öğretmen-merkezli pedagojik inançlara sahip olan bir öğretmen, öğretilecek konuları merkezileştirir (Cornelius-White ve Harbaugh, 2009). Başka bir deyişle konu kapsamları, kavramlar, ilkeler, teoriler, doğa yasaları, şiirler ve metin paragrafları; sistematik olarak öğrenilmesi gereken konu yığınlarıdır (Cornelius-White ve Harbaugh, 2009). Öğretmen-merkezli bir sınıfta edinilecek konunun ana kaynakları; öğretmen, müfredat, ders kitapları ya da diğer uzmanlardır (Cornelius-White ve Harbaugh, 2009). Konular merkeze alındığında, konuları daha iyi bilen merkezi bir konuma yükseltilir. Bu nedenle, sınıfta gerçekleşen olayların odağında konuyu diğerlerinden daha üst derecede bilen öğretmen yer alır. Dolayısıyla bu tip bir pedagojik yaklaşıma sahip olan öğretmenin sınıfında sistemde sadece öğretmen yer alır. Diğer taraf, ya da öğrenenler, yok sayılabilir. Öte yandan, öğrenen-merkezli yaklaşım, öğretimsel süreçlerin başka bir türünü ya da eğilimini ifade eder. Öğretmen kendisi ile diğerlerinin de sınıftaki bilişsel ve sosyal varlığını kabul eder ise sistemde temelde iki öğe yer alır; öğretmen ve öğrenci (Åkerlind, 2003; 2004; 2007; 2008). Bu pedagojik eğilimde öğrenenlerin herhangi bir konu aracılı̆̆ıla belli başlı becerileri tecrübe etmesi beklenir. Öğretilecek konuların merkezileşmesinden ziyade ilgili konular yoluyla tecrübe edinilecek becerilerin merkezileşmesi; öğrenen-merkezli pedagojik inanç sistemleri içinde daha fazla kabul görür. Tecrübe ediciler, öğrencilerdir ve öğrenen-merkezli bir yaklaşım, esasında beceri-merkezli bir yaklaşımı da ifade eder. Öğretim, öğretmen tarafından tek yönlü, öğretmen- ya da konu-merkezli olarak algılandığında, sistemden öğrencilerin bilişsel ve sosyal katkıları ya da varlıkları elemine edildiğinde, öğretmen için sınıf yönetimine ait sapmaların olmayacağı ya da olumsuz davranışların gözlemlenmeyeceği algısı ortaya çıkabilir. Çünkü bu sistemde öğretmen anlatacak, öğrenciler ise öğretmeni dinleyerek öğreneceklerdir (Bolhuis ve Voeten, 2004). Birçok eğitimci bu tipte bir öğretimi, "çantada keklik" (taken-for-granted) olarak nitelerler (Åkerlind, 2003; 2004; 2007; 2008). Ancak öğrenenler, öğretmeni sadece dinlerken dahi, çok yönlü ve diyalojik bir süreç içinde yer alırlar (Bakhtin, 1934; 1986 Mortimer ve Scott, 2003). Öğretmenin anlattıklarını dinleyen öğrenciler, sessiz konumda kalsalar dahi, kendi dilsel ve düşünsel sistemleri ya da kendi kavramları ve yorumlamaları ile öğretmenin söylemlerini sürekli gözden geçirirler. Bilindiği üzere öğrenenlerin sınıf ortamına getirdiği dil-düşünsel sistemler ya da kavramsal ekolojiler, çoğunlukla okulda ulaşılması hedeflenen ya da öğretmenin dil-düşünsel sisteminden (oldukça) farklı olabilir (Leach ve Scott, 2002). İki farklı dil-düşünsel sistemin olması, öğrencilerin öğretimsel süreçlerden kopmasına ve/ya uzaklaşmasına, dolayısıyla çeşitli olumsuz davranışların ortaya çıkmasına yol açabilmektedir. Çünkü her ne kadar öğretilecek olgu ya da kavram, doğada ya da toplumda tek olsa da öğrenenlerin bu kavramlarla ilgili sınıf ortamına taşıdıkları yorumlamalar daha heterojen bir yapıyı işaret edebildiğinden, farklılaştırılmış bir kavramlar ve yorumlamalar bütünü kaçınılmazdır (Mortimer, Scott ve El-Hani, 2012).

Öğretmen bu kavramsal ya da dil-düşünsel ayrıksılığa iki şekilde reaksiyon verecektir ve bu reaksiyon tipolojileri çoğunlukla öğretmenin pedagojik inanç sistemi ile ilgilidir; ya öğrenenlerin sınıf ortamına günlük yaşantıları itibariyle rastgele bir şekilde taşıdı̆̆ı kavramları görmezden gelip okul biliminin sosyal dilini öne çıkaracak ya da öğrenciler aracılığıyla oluşturulan 
kavramsal çeşitliliğe reaksiyon vererek, onları da sistem içine dâhil edecek ve entelektüel etkileşimleri öğrenenlerin kavramsal ekolojileri üzerinden devam ettirecektir. Bu durum öğretmen için ciddi bir pedagojik gerilim oluşturur ve pedagojik bir karar verme süreci gerektirir. Beklendik bir şekilde öğretmen, eğer öğrenenleri sisteme dâhil etmez ise olumsuz davranışların gözlemlenme sıklığının artması olasıdır. Çünkü kavramsal olarak sürece bilişsel olarak bağlanamayan öğrenenlerin daha çok olumsuz davranış gösterme olasılığının olduğu bilinmektedir (Baer, 2015; Bradshaw, 2014). Öğrenenler ancak ve ancak kendi dil-düşünsel sistemleri de önemsendiğinde ve öne çıkarıldığında sınıf içi süreçlere temas etme ve bunlara bağlanma eğilimindedirler (Baer, 2015; Bradshaw, 2014) dolayısıyla öğretmen, alternatif sesleri hoş görür, öğrenenlerin sınıf ortamına taşıdığı dilleri onların aracılığı ile irdeler, onların içindeki kavramsal, epistemolojik ve ontolojik yanılgıları onlara gösterir ve öğrencilerin kendi kavramları üzerine sıkça yeniden düşünmesini sağlayabilirse öğrenenler; sürece esaslı bir şekilde katkıda bulunan ve öğrenilecek olguyu öğretmenle birlikte eş bir şekilde inşa eden eş-görevliler hâline dönüşebilirler. Dolayısıyla entelektüel olarak yüklenmiş ve bağlanmış olan öğrenenler, olumsuz davranış sergileme değil, ögrenme olgusunu beraber yapılandırma ile ilgili bir görevi ya da süreci üstlenmiş olurlar.

Bu durum, Candela'nın (2005) sınıf yaşamını tanımlamak üzere ürettiği "sınıfın beklendik olayları" ve "sınıfın beklenmedik olayları" olguları ile de açıklanabilir. Bu bağlamda öğretmenler için sınıfta gerçekleşmesi önceden bilinen-tahmin edilen ve önceden bilin(e)meyen ve-tahmin edil(e)meyen olaylar bütünü, mevcuttur (Candela, 2005; Lefstein, 2008; Lin, 2007). Esasen öğretmenlerin bir öğretim ajandası vardır ve öğretmenler, genellikle bu öğretimsel ajandayı uygulamak isterler. Bu bağlamda sorulması gereken en önemli soru, ögretmenlerin sinıfin beklendik ve beklenmedik olaylarına nasıl ve ne yönde pedagojik reaksiyonlar verdiği, bunları neyin yönettiği ve tüm bunların olumsuz davranışların varlı̆̆ına etkisidir. Bu anlamda öğretmenlerin pedagojik reaksiyonlarını açıklayan olgunun onların öğrenmeye ve ögretmeye yönelik zaman içinde geliştirdikleri pedagojik inanç sistemleri olduğu söylenebilir. Öğretmenlerin pedagojik inanç sistemleri (öğrenmeye ve öğretmeye yönelik algılar ve kabuller bütünü) onların sınıf içi karar verme ve uygulama süreçlerini hem belirlemekte hem de yönetmektedir (Pajares, 1992; Richardson, 1996; Wall, 2016). Öğretmen, eğer daha konu-merkezli bir pedagojik algıya sahipse öğretim ajandasının dışına çıkan öğrenci seslerini ve katkılarını öğretimin akışında herhangi bir sapma ya da bozulma olmaması için yok sayacak ya da görmezden gelebilecektir. $\mathrm{Bu}$ durum bireyselleştirilmiş bir öğretmen-temelli öğretim ajandası dışında kalanlar (öğrenciler) için süreçlerin dişında tutulma durumu oluşturabilecektir. Entelektüel anlamda herhangi bir yükümlülük al(a)mayan ya da almasına izin verilmeyen ve öğretimsel ajandanın dışında tutulan öğrenenler ise çeşitli olumsuz davranışları (yüksek ihtimalle) gösterme durumunda olabileceklerdir.

Öte yandan, bir öğretmen her ne kadar müfredat-temelli çeşitli sorumluluklara sahip olsa da öncesinde oluşturduğu öğretimsel ajandanın dışında olan alternatif seslere ve katkılara yer verebilir ve sınıftaki öğrenci davranışlarından ziyade, öğretimsel olarak alternatif yorumlamaları nasıl yöneteceğini hedefleyebilir. Bu öğretmen öğrenen-merkezli bir öğretimsel algıya sahip olduğu söylenebilir. Kavramsal, epistemolojik ya da ontolojik olarak öğretimsel ajandadan (akıştan) sapma gösteren öğrencilerin söylemleri ile ilgilenmek, onları öne çıkarıp öğrenenlerin neden bu tipte bir akıl yürütmeye sahip olduğunu irdelemek ve öğrenenleri, fikirlerini müzakere etmek üzere tartışmalara davet etmek, öğrenenlere ciddi bilişsel yükler yükleyeceği ve onlarda çeşitli bilişsel talepler yaratmaktadır. Bu tip öğretme- öğrenme ortamlarında yüksek ihtimalle olumsuz davranış gösterme durumları ve oranları en düşük düzeylerde seyredecektir. Sonuç olarak 
öğretmen, sınıf içi etkileşimler adına hem beklendik hem de beklenmedik olayları, söylemleri, argümanları, yorumlamaları ya da kavramsallaştırmaları göz önünde bulundurabildiği ölçüde olumsuz davranışların sergilenmesini engelleyebilecektir. Çünkü sınıf yönetiminde beklendik davranışların değil, beklenmedik davranışların yönetilmesi esastır. Bu argüman, sınıf yönetimi adına en genelleyici çalışmaların raporladığı sınıf içi dinamiklerinin esasları ile de örtüşmektedir. Araştırmacılar, açık bir biçimde sınıfta gerçekleşecek olayların çok yönlü olduğunu ifade etmektedir. Ek olarak sınıf-içi olaylar ve kişiler, sürekli değişkenlik ve çeşitlilik gösterebilir. Ayrıca, sınıfta olaylar eşzamanlı olarak meydana gelir; birçok beklenmedik olay, anlık olarak aynı anda gerçekleşebilir. Bu durum hem öğretimsel akış hem de sınıf yönetimi adına bir tahmin edilemezlik durumunu kısmi olarak doğrular. Ötesinde hızla gerçekleşen olaylar, sınıfta olaylar nedeninin ve nasıllığının sorgulanmasına izin vermeyebilir ve öğretmenin vereceği anlık pedagojik kararlarla çözümlenebilir ya da daha da karmaşık hâle getirilebilir. Görüldüğü üzere sınıf yönetimi olgusu öğretimsel perspektifin ya da eğilimin türü ile ciddi derecede senkronizedir. Başka bir deyişle, olumsuz davranışların ortaya çıkması, zorunlu olarak öğretmenin benimsediği teorik sisteme (pedagojik inançlar, kavramlar, algılar, iddialar vs.) ve bunun sınıf içi yansımasını ifade eden öğretimsel perspektife bağlıdır. Tüm bunlara ek olarak, öğretimsel perspektifin içine gömülmüş, sınıf yönetimi ilkelerini kontrol eden ve düzenleyen iki tez daha yer almaktadır. Bunlar benimsenmiş öğretimsel perspektifin yarattığı ya da ortadan kaldırdığı otorite olgusu ve yine öğretimsel perspektife bağlı olan söylemsel güç ilişkileri olarak listelenebilir. İlerleyen bölümde otorite olgusu ve söylemsel güç ilişkileri olgusu, öğretimsel perspektif bağlamında sınıf yönetimi olgusuna bağlanacaktır.

\section{Sinıf yönetimi ve otorite olgusu}

Bir öğretmenin sahip olduğu pedagojik inanç sistemleri ve eğilimleri öğretimsel perspektifi belirler ve biçimlendirir. Sınıf içinde öğretmenin rutin bir biçimde uyguladığı öğretimsel yaklaşımlar, olumsuz davranışların ortaya çıkması ya da çıkmaması noktasında artalanda iki belirleyici faktöre bağlanır. Bunlar değişen sınıf içi otorite olgusu ve söylemsel güç ilişkileridir. Başka bir deyişle öğretmen ve öğrenenler arasındaki sözel ve sözel olmayan etkileşimler, bir otorite olgusunu ve söylemsel güç ilişkisini tanımlar ve bunlar sınıf kültürüne dâhil olanlar için bilinçli (direkt) ya da bilinçli olmadan (dolayli) hissedilebilir ya da anlaşılabilir. Bu bağlamda, Rogers ve Freiberg (1994) öğrenen-merkezli ve öğretmen-merkezli sınıf ortamlarındaki sınıf yönetimi ile ilgili durumları karşılaştırmışlardır. Bu karşılaştırma, Tablo 1'de ayrıntılı bir şekilde gösterilmiştir. Rogers ve Freiberg'in (1994) karşılaştırması sınıfta otorite olgusunun yer aldığını göstermektedir. Otoritenin olduğu bir bağlamda çeşitli söylemsel güç ilişkilerinden bahsedilebilir. Söylemsel güç ilişkileri, öğretmen-merkezli bir sınıfta daha asimetrik; öğrenen-merkezli bir sınıfta ise daha simetrik bir hâl alabilir (Kounin, 1970).

Öğrenen-merkezli ya da öğretmen-merkezli öğretimin gerçekleştirildiği bir sınıfta genellikle iki tip otorite oluşumundan bahsedilebilir: (i)epistemik otorite, (ii)sosyal otorite (Berland ve Hammer, 2012). Epistemik otorite bilgiye dair bir otoritedir. Sınıfta bilgiye kim sahipse ya da bilgiyi kim oluşturuyorsa epistemik otorite de odur. Öğretmen-merkezli öğretimin benimsendiği sınıflarda tek ve tartışılmaz otorite, konu içeriğine daha fazla sahip olan öğretmenlerdir. Daha da önemlisi epistemik otoriteyi elinde bulunduran, sınıfta aynı zamanda sosyal otoritedir (Glasser, 1998). Sosyal otorite, sınıfta sosyal etkileşimlerin nasıl olması gerektiğini belirleyen kişi ve/veya kişilerden oluşur. Eğer bir sınıfın tek epistemik otoritesi öğretmense sosyal otorite de o olacaktır. Sınıfın sosyal otoritesi ve epistemik otoritesi aşağıdaki sınıf içi durumları belirler (Candela, 2005; 
Myhill, 2006; Lefstein, 2008; Lin, 2007; Lyle, 2008) ve bu unsurlar aynı zamanda Tablo 1'de de ayrıntılandırılmıştır. Bir sınıfta epistemik ve sosyal otoriteyi aşağıdaki maddeler karakterize edebilir:

- Kim ne zaman konuşacak (sosyal otorite?)

- Kimin konuşacağına kim karar verecek (sosyal otorite?)

- Kim ne kadar süre ile konuşacak (sosyal otorite?)

- Kimin söylediği doğru ya da rasyonel olarak kabul edilecek (epistemik otorite?)

- Hangi bilgiler, doğru kabul edilmeyecek (epistemik otorite?)

- Hangi öğrenen söylemleri, sınıf diyalogundan elenecek (epistemik otorite?)

- Hangi öğrenen katkıları gerçek bilişsel katkılar olarak öne çıkarılacak (epistemik otorite?)

Tablo 1*. Öğretmen-merkezli ve Öğretmen-merkezli pedagojik yaklaşımlarda sınıf yönetimi durumlarının karşılaştırılması

\begin{tabular}{|c|c|}
\hline KONU-MERKEZLİ & BECERI-MERKEZLİ \\
\hline Sinıfta tek lider öğretmendir. & Sinıfta liderlik paylaşılmıştır. \\
\hline Sınıf yönetimi bir hata bulma işidir. & Sınıf yönetimi bir yönlendirme işidir. \\
\hline $\begin{array}{l}\text { Sinıfin tüm organizasyonu ile işleri } \\
\text { öğretmenin sorumluluğundadır. }\end{array}$ & $\begin{array}{l}\text { Tüm öğrenenler sınıf organizasyonunda } \\
\text { öğretmenin destekleyicileridir. }\end{array}$ \\
\hline Disiplin öğretmenden gelir. & Disiplin özden (öğrenenden) gelir. \\
\hline $\begin{array}{l}\text { Sadece birkaç öğrenen öğretmene sınıf } \\
\text { yönetiminde yardımcı olur. }\end{array}$ & $\begin{array}{l}\text { Tüm öğrenenler sınıf yönetiminde etkili } \\
\text { sorumluluk almada firsatlara sahiptir. }\end{array}$ \\
\hline $\begin{array}{l}\text { Öğretmen sınıf kurallarını koyar ve } \\
\text { öğrenenlere direkt iletir. }\end{array}$ & $\begin{array}{c}\text { Bir sözleşme ve/veya müzakere sonucunda } \\
\text { sinıf kuralları ögretmen ve öğrenenler } \\
\text { tarafından oluşturulur. }\end{array}$ \\
\hline $\begin{array}{l}\text { Uyumsuz/uyumlu davranışların sonuçları } \\
\text { bütün öğrenenler için net ve tektir. }\end{array}$ & $\begin{array}{l}\text { Uyumsuz/uyumlu davranışların sonuçları } \\
\text { bireysel farkl11ıkları yansıtır. }\end{array}$ \\
\hline $\begin{array}{l}\text { Öğrenenler sınırlı görev alma } \\
\text { sorumluluğuna sahiptir. }\end{array}$ & $\begin{array}{l}\text { Tüm sınıf sorumluluğu herkes tarafından } \\
\text { paylaşlır. }\end{array}$ \\
\hline
\end{tabular}

* Ilgili kaynaktan türetilmiştir: Rogers, C. and Freiberg, H.J. (1994) Freedom to learn. 3rd ed. New York: Macmillan Publishing.

Epistemik otoritenin paylaşılmadığı, dolayısıyla sosyal otoritenin tekleştiği sınıflarda öğretmen-merkezli bir öğretimsel süreç ilerletiliyor demektir. Bu bağlamda öğretmenin iki tip rolü olabilir: (i) öğretimsel süreçlerin nasıl başlayacağını ve devam edeceğini söyleyen ve yönlendiren kişi olmak; (ii) öğretimsel süreçlerin sonunda ortaya çıkan entelektüel ürünlerin işe yarayıp yaramadığını belirleyen kişi olmak (Lin, 2007; Mameli ve Molinari, 2013).

Ancak öğretmenler, her zaman hem epistemik hem de sosyal otorite olmayabilirler. Otorite paylaşımının hâkim olduğu sınıf yönetimi süreçleri de mümkündür ve bu durumda öğrenenmerkezli bir öğretimsel süreç işletiliyor olabilir (Freiberg, 2007). Öğrenen-merkezli öğretimsel süreçlerde iki tip otorite de paylaşılabilir. Açıklamak gerekirse eğer öğretmenler, öğrenenlerin de sınıfta oluşturulan öğrenme olgularına bilişsel katkıda bulunmalarına izin verirlerse öğrenenler, epistemik anlamda bir otorite kazanmış olurlar (Glasser, 1969, 1986). Çünkü öğrenenler; öğrenme olgularına bilişsel katkıda bulunurken birbirlerini dinler, verilen cevapları derinleştirir, diğerlerinin 
cevaplarını eleştirebilir ve yargılar, toplamda ise hangi argümanın doğru, işe yarar ya da sınıf içi süreçler için ilerletici olduğuna karar verebilirler (Soysal, 2017; 2018). Başka bir deyişle öğrenenler öğrenme-merkezli süreçlerde kendi araştırmaları ve müzakereleri aracılığıyla argümanlarını ve bilgilerini üretebilmiş olurlar. Böylelikle epistemik otoriteyi elde etmiş olabilirler (Freiberg, 1999). Bu bağlamda öğretmen, epistemik otoritesini diğer sınıf üyelerinin de öğrenmeye katkıda bulunması aracılığıyla paylaşmıştır. Bu noktada ciddi derecede önem arz eden diğer bir sınıf yönetimi unsuru ise şudur: "Epistemik otoriteye zamanla sahip olan öğrenenler, aynı zamanda sınıfın sosyal otoritesi de olmaya başlayacaklardır”. Tüm öğrenenler sırasıyla öğrenme olgusuna kasıtlı katkıda bulunmak amacıyla müzakere süreçlerine birbirlerini davet edebileceğinden; kimin ne kadar, ne zaman, hangi sıra ile konuşacağına karar verebileceğinden; hangi fikrin ya da argümanın kabul edilip hangilerinin kabul görmeyeceğini belirleyeceğinden eş-sosyal otoriteler hâline dönüşürler (Good ve Boophy, 2003). Dolayısıyla öğretmenler, epistemik otoritesini ya da baş/ asıl bilici rolünü (primary knower role) ve sosyal otoritesini diğer sınıf üyeleri ile paylaşmış olacaktır (Berry, 1981; Lemke 1990; Mameli ve Molinari, 2013).

Özetle iki tip otoritenin paylaşımının gerçekleştirildiği ölçüde daha etkin bir sınıf yönetiminin, dolayısıyla daha az uyumsuz öğrenen davranışının ortaya çıkması muhtemeldir (Bartlett, 1994; Bauman, 1992). Daha da önemlisi öğrenen-merkezli bir öğretimsel süreçte otorite tipleri, tek bir kaynakta toplanmadığından ve belli dereceye kadar eşit bir şekilde paylaşılabildiğinden, öğretmen ve sınıfın diğer üyeleri (öğrenenler) birer otorite hâline gelmiştir. Tek otoritenin baskın olduğu sınıflar, bilişsel olarak daha az bağlanmış ve yüklenmiş öğrenenleri içereceğinden bu sınıflarda daha fazla olumsuz davranışın görülmesi muhtemeldir. Birden fazla ya da paylaşılmış otoritenin yer aldığı sınıflarda ise öğrenenler, öğrenme olgusuna entelektüel katkıda bulunma (epistemik otorite) ve sosyal akışı düzenleme (sosyal otorite) anlamında birinci derecede sorumlu olduklarından olumlu davranışların görülmesi daha muhtemeldir (DeVries ve Zan, 1994; Dollard ve Christensen, 1996).

Tüm bu argümanların ve yorumlamaların ötesinde, gerçek öğrenen-merkezli sınıflarda sınıf yönetimi adına herhangi bir otoriteden söz etmek bir anlam taşımayabilir. Desteklemek gerekirse, tüm sınıf üyelerinin hem epistemik hem de sosyal otorite olduğu öğretimsel anlarda otorite olgusu sistemden kendiliğinden elemine olacaktır. Açıklamak gerekirse, baskın otoritenin yer aldığ sistemlerde otorite olgusundan bahsedilebilir. Nicel ve nitel olarak farklılaştırılmış ya da derecelendirilmiş otoritelerin varlığında otorite olgusu, sınıf yönetimi adına görünür hâline gelir. Ancak, otorite bilişsel eş-sorumluluklar ve eş-katkılar aracılığıyla paylaşılmış ve tüm üyeler otorite kılınmışsa her birey otoriterleşmiştir ve otorite, sınıfın rutin olgusu hâline dönüşmüştür. Başka bir deyişle, otorite olma olgusu adına nitel ve nicel farklılaşmalar ortadan kaldırılmıştır. Sonuç olarak her bireyin otorite olduğu bir öğretimsel dokuda otoriteden bahsedilemez. Başka bir değişle, otoritenin yok edilmesinin en iyi yolu otoritenin paylaşılmasıdır (Broophy, 1999, 2006; Martin, 2004). Olumsuz davranışların ortaya çıkmasına sebep olan esas unsur, paylaşı1(a)mamış otoritedir. Dolayısıyla öğretmenler, epistemik ve sosyal otoriteyi paylaşabildikleri ölçüde olumsuz davranışların azalmasını ve zamanla yok olmasını hem garantileyebilir hem de tayin edebilirler.

\section{Sınıf yönetimi ve söylemsel güç ilişkileri olgusu}

Öğrenme ve öğretme olgusunu direkt olarak sınıf içi söylemsel ilişkiler aracılığıyla derinlemesine araştıran birçok araştırmacının vardığı en önemli noktalardan birisi, öğretimsel yaklaşımlar ile bunların sınıf içinde öğretmen konuşması ile canlandırılması arasında ciddi bir 
ilişkinin ve belirleyiciliğin olduğu yönündedir (Lemke, 1990; Scott, 1998). Öğretimsel yaklaşımın türü, öğretimin nasıl başlayacağını, devam edeceğini ve sonlanacağını belirler. Dolayısıyla müfredat teknisyenleri, her biri konu için özellikli öğretimsel yaklaşımların belirlenmesi amacıyla çeşitli deneysel çalışmalar yürütmüş ve özellikli öğretimsel teknikler ve stratejiler belirlemişlerdir (Brown ve Clement 1991; McDermott ve Somers 1991; Viennot ve Rainson, 1999). Ancak özellikli bir konu için özellikli bir öğretimsel yaklaşımın belirlenmesi, her ne kadar sınıf içi etkileşimleri etkiliyor ve tahmin ediyor olsa da ilgili öğretimsel yaklaşımları işe-vuruklaştıran ya da sahneleyen öğretmen konuşması da ciddi derecede önem arz etmekte, sınıftaki otorite olgusu ve güç ilişkileri de öğretmen konuşmasının söylemsel içeriğine göre belirlenmektedir (Soysal, 2017; 2018). Hatta, bazı araştırmacılar; öğretimsel tarz, yaklaşım, teknik veya stratejilerin ötesinde sınıf içi ilişkileri karakterize eden ve belirleyen faktörün öğretmenin konuşması aracılığıyla öğrenenlere verdiği söylesel mesajlar olduğunu ifade etmektedirler (Scott, 1997; Soysal, 2017). Çünkü her bir öğretimsel perspektif, ona eşlik eden bir öğretmen konuşması tarafından çevrelenir (Scott, 1997; 1998). Bu argüman, bu araştırma bağlamında, öğretimsel yaklaşımın belirlediği pedagojik perspektifin önemsiz olduğunu göstermez; öğretmen konuşmasının analitik parçalarının otorite olgusunu ve söylemsel güç ilişkilerini sıklıkla ve sürekli olarak devindirdiğini ifade eder.

Öğretmenin planladığı ve uyguladığı öğretimsel yaklaşımların, tekniklerin veya stratejilerin otorite olgusunun sınıf içinde varoluşunu alt üst edebildiği söylenebilir (Freiberg, 1999a; 1999b). Rogers ve Freiberg (1994), Tablo 2'de gösterildiği üzere, sınıf yönetimi süreçlerinin fazlaca etkilendiği çeşitli öğretimsel uygulama türlerini belirtmişlerdir. Rogers ve Freiberg (1994) bu kategorizasyonu öğretmen-merkezli öğretimsel aksiyondan, öğrenen-merkezli öğretimsel aksiyona keskin bir geçiş ya da "var-yok" şeklinde değil, devamlılık arz eden, dereceli bir şekilde oluşturmuşlardır. Tablo 2'de görüldüğü gibi öğretmen-merkezli öğretimsel aksiyonlardan daha öğrenen-merkezli öğretimsel aksiyonlara dereceli bir geçişin olduğu görülmektedir. Sınıf yönetimi bağlamında ise yukarıdan aşağıya doğru daha az uyumsuz öğrenen davranışının görüleceği, otorite tiplerinin paylaşımının daha fazla olacağı, sınıf yönetiminin hem öğretmen hem de öğrenenler tarafından üstlenileceği söylenebilir (Freiberg, 1999a, 1999b). Örneğin direkt anlatımın baskın öğretimsel anlayış olduğu sınıf içi süreçlerde öğrenenler hem epistemik hem de sosyal otorite olma durumlarını baştan yitirmişlerdir (Cornelius-White, 2007). Direkt anlatımın olduğu sınıflarda öğretimsel akış; öğretmen anlatır, öğrenenler anlar silsilesinde gerçekleşir (Cornelius-White, 2007; Soysal ve Radmard, 2017a; 2017b; 2018; Soysal ve Tanık, 2017). Doğrudan anlatıların hâkim olduğu öğretimsel süreçlerde çoğu öğretmen, disiplin kurallarının işletildiğini varsayabilir. Başka bir deyişle otoriter (despot, baskın) bir öğretmenin sınıfında direkt olarak anlatılan konuları (tedirginlik atmosferinde) dinleyen ve (sözde) kavramaya çalışan öğrenenler olabilir. Bu tip bir sınıfta disiplin sağlanmış gibi görünebilir; çünkü sadece öğretmenin sesi net bir şekilde duyulmakta, onun direkt anlatısını olumsuz etkileyecek herhangi bir uyumsuz davranışla karşılaşılmamaktadır. Burada esas sorulması gereken soru şudur: "Bu durum sınıf yönetiminin gerçekten planlandığı ve uygulandığı anlamına mı gelir?” Cevap ise bu tipte bir öğretimsel yaklaşımın sınıf üyelerini baskılayarak sınıf yönetimini mümkün kıldığı ve olumsuz davranışların gözlemlenmemesinin esas sebebinin fazlaca asimetrik otoriteden kaynaklandığı yönündedir. Esas itibariyle, sınıf yönetimi, sınıf üyelerini öğretmenin ağzından çıkan şeyleri dinler hâle dönüştürmenin ya da salt bir şekilde disipline etmenin tarifi olmaktansa öğrenmenin bizzat gerçekleştirilmesi ve artırılması için yerine getirilen, öğretmen ve öğrenenlerce üstlenilmesi gereken, sosyal sorumluluklar bütünüdür (Freiberg ve Lapointe, 2006). 
Tablo* 2. Öğretmen-merkezli ve Öğretmen-merkezli pedagojik yaklaşımlarda öğretimsel süreçlerin dereceli geçişi ve sınıf yönetimi

\begin{tabular}{|c|c|}
\hline \multicolumn{2}{|r|}{ DAHA ÖĞRETMEN-MERKEZLİ } \\
\hline Direkt anlatım & Öğretmen içeriğin direkt olarak sunulmasında aktif bir rol alır ve \\
\hline & öğrenenlerin yapması gereken şey dinlediklerini anlamak ve öğrenmektir. \\
\hline$\ddot{U} c ̧ l \ddot{u}$ diyalog & $\begin{array}{c}\text { Öğretmen-öğrenen ilişkisi üçlü diyalog dizgileri içinde kalır. Öğretmen } \\
\text { bir soru ile süreci başlatır (Başlat); öğrenenler öğretmeni memnun etmek } \\
\text { için cevap verirler (Cevap Al); öğrenenlerin cevapları sadece öğretmen } \\
\text { tarafından değerlendirilir (Değerlendir). }\end{array}$ \\
\hline Ezberle-Yap & $\begin{array}{l}\text { Öğretmen önce bir kavramı tanıtır, sonra o kavramı pekiştirmek için } \\
\text { bireyleri bir pratik görev üzerinde bağımsız çalıştırır. }\end{array}$ \\
\hline Gösterip & Öğretmen öğrenenlere bir materyalin ya da özel bir aletin nasıl \\
\hline yaptırma & kullanılacağını gösterir ve ondan yapmasını bekler. \\
\hline Tartışma & $\begin{array}{c}\text { Öğretmen öğrenenlerin rahat bir şekilde alternatif argümanları } \\
\text { sunabilecekleri ve öğrendiklerini üst düzey becerilerle yeniden } \\
\text { anlamlandırabilecekleri ortamlar hazırlar. }\end{array}$ \\
\hline $\begin{array}{l}\text { Iş̧birlikli } \\
\text { çalışma }\end{array}$ & $\begin{array}{l}\text { Küçük çalışma ya da araştırma grupları birbirine bağlılık, bireysel } \\
\text { sorumluluk ve kolektif çalışma ile görevleri yerine getirirler. }\end{array}$ \\
\hline Yönlendirilmiş & Öğretmen öğrenenlere önceden yapılandırılmış bir problem ya da \\
\hline keşif & $\begin{array}{c}\text { problemler durumunu sunar, bu problem durumunun nasıl çözümleneceği } \\
\text { ile ilgili aşamaları onlara sağlar. }\end{array}$ \\
\hline Sosyal & Öğretmen öğrenenlerle birlikte yapılacak iş ya da görevin nasıl ve ne \\
\hline kontratlar & zamana kadar yapılacağını belirten bir yazılı metni imzalar. \\
\hline Rol oynama & $\begin{array}{c}\text { Öğrenenler gerçek hayat problemlerini çözümlemek ya da biçak sırtı } \\
\text { konularda karar vermek için çeşitli rolleri icra ederler. }\end{array}$ \\
\hline Projeler & $\begin{array}{l}\text { Bilimsel bir araştırma ve raporlama süreci öğrenenlerce bir durumun } \\
\text { keşfedilmesi ya da bir konunun derinlemesine öğrenilmesi için yürütülür. }\end{array}$ \\
\hline Araştırma- & Öğrenenlerin kendi araştırma sorularını oluşturup, veri toplama \\
\hline sorgulama & $\begin{array}{l}\text { süreçlerine girdiği ve öğrenilen konular hakkında eleştirel düşünebildiği } \\
\text { öğretimsel yaklaşımdır. }\end{array}$ \\
\hline $\mathrm{Oz}-$ & Öğrenenlerin objektif ölçüler çerçevesinde kendi düşünmesini veya \\
\hline dĕgerlendirme & \\
\hline & DAHA ÖĞRENEN-MERKEZLİ \\
\hline
\end{tabular}

* ilgili kaynaktan türetilmistitir: Rogers, C. and Freiberg, H.J. (1994) Freedom to learn. 3rd ed. New York: Macmillan Publishing.

Öte yandan öğretmenin öğretimsel yaklaşımı öğrenen-merkezli bir süreci yansıtabilir. Öğrenenlerin sesinin daha çok duyulduğu, onların öğrenme olgusuna entelektüel katkılarının nicel ve nitel açıdan daha yeterli düzeylerde bulunduğu bir sınıfta, sınıf yönetimi olgusu; başka bir anlam taşıyabilecektir. Örneğin araştırma-sorgulamaya dayalı öğretimsel uygulamalarda sınıf yönetimi adına öğretmenin alacağı sorumluluklar başkalaşabilir. Bu tipte öğretimsel bir perspektifte öğretmen; öğrenenleri susturmak, kendisini pür dikkat dinlemelerini sağlamak, sınıfta süregelen sessizliği kesinleştirmek gibi görevleri icra etmez.

Bunlar yerine öğretmen; pedagojik açıdan "öğrenenler rasyonel araştırma soruları oluşturabildiler mi?”, "küçük grup çalışmalarında öğrenenler grup çalışmasına yeterince katkıda 
bulunuyorlar mı?”, “öğrenenler örneğin deneysel ya da araştırma süreçlerini geçerli ve güvenilir bir şekilde yürütebiliyorlar mı?”, "öğrenenler proje ya da araştırma sonuçlarını birbirine sunarken veri ve delil temelli akıl yürütmeler yapabiliyorlar mı?" gibi soruları gerçek sınıf yönetimi adına cevaplamaya çalışacaktır. Bu bağlamda öğretmen, salt bir sınıf yönetimi icrasına yönelmektense öğrenenlere araştırma-sorgulama gibi bir öğretimsel sürecin gerçekleşmesi için çeşitli sorumluluk bilinçlerinin kazandırılmasının yollarını arayan ve uygulayan kişi olarak görev yapmaktadır (Cornelius-White, 2007).

Ötesinde bu tipte bir öğretmenin sınıfinda sessizlik değil, araştırma süreçlerinden dolayı oluşan ciddi bir gürültü hâkimdir. Ancak bu gürültü "üretken” bir gürültüdür ve öğrenenlerin öğrenme süreçlerine katkıda bulun(a)madıkları ve sınıftaki akseden olaylara bağlan(a)mayıp kendilerini ait hissetmedikleri için uyumsuz davranışlarından doğan "üretken olmayan" gürültüden oldukça farklıdır (Cornelius-White, 2007). Özetle, yukarıdaki gibi düşünüldügünde sınıf yönetiminin biçimini ve görünümünü asıl değiştiren olgunun öğretimsel aksiyonların ya da yaklaşımların tipi olduğu söylenebilir. Ancak bu öğretimsel aksiyonlar ve yaklaşımlar, ciddi derecede öğretmen konuşmasından etkilenir ve bu bölümün başında da belirtildiği üzere öğretmen konuşması, her bir öğretimsel dizgenin daha öğretmen-merkezli mi yoksa daha öğrenen-merkezli mi olduğunun belirlenmesi bağlamında bir ölçüt olarak kullanılabilir. Öğretimsel yaklaşımı ya da akışı çevreleyen ve onu başka bir pedagojik etkileşime dönüştürebilen öğretmen konuşması, aşağıdaki örneklerle daha iyi anlaşılabilecektir.

Tablo 3 ve Tablo 4'te bir öğretmenin sınıf içi sözel ve/veya sözel olmayan etkileşimleri yaptığı konuşma ya da pedagojik hamleler aracılığıyla nasıl değiştirebileceğini ve bunun otorite ve güç ilişkilerine nasıl yansıdığını gösteren iki farklı örnek sunulmuş ve karşılaştırılmıştır. İlgili örnekler, 2016-2018 eğitim-öğretim yılında, yedinci sınıf öğrencilerinin dahil olduğu bir fen dersinden kesit olarak alınmıştır. Diyalog dolayısıyla kurgusal değil, gerçektir. Birinci örnek (Tablo 3), daha asimetrik güç ilişkilerini ve dağıtılmamış otoriteyi gösterirken ikinci örnek (Tablo 4) ise daha simetrik güç ilişkilerini ve paylaşılmış otoriteyi temsil etmektedir. Öğretimsel aktivitenin öğretmenin çevreleyici pedagojik hamleleri ile nasıl devindirildiği ve bunun sınıf yönetimi durumlarına nasıl yansıdığı, diyalogların çözümlenmesi ve yorumlanması aracılığıyla göstermektedir.

Tablo* 3. Diyalog-I ve daha asimetrik söylemsel güç ilişkileri

\begin{tabular}{|c|c|c|c|c|c|}
\hline$\stackrel{2}{2}$ & 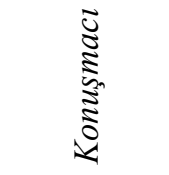 & Diyalog & $\begin{array}{l}\text { Konuşma } \\
\text { örüntüsü }\end{array}$ & $\begin{array}{l}\text { Söylemsel } \\
\text { hamle }\end{array}$ & Fonksiyon \\
\hline 1 & Öğretmen & $\begin{array}{l}\text { Evet, maddenin içinde ne } \\
\text { var çocuklar? }\end{array}$ & Başlat (B) & $\begin{array}{l}\text { Kapal1- } \\
\text { uçlu soru }\end{array}$ & $\begin{array}{l}\text { Diyalogu başlatmak için } \\
\text { öğretmenin sorduğu soru }\end{array}$ \\
\hline 2 & Öğrenci-1 & Parçacıklar var. & Cevap al (C) & - & - \\
\hline 3 & Öğretmen & $\begin{array}{c}\text { Tamam da işte onlara ne } \\
\text { diyoruz? }\end{array}$ & $\begin{array}{l}\text { Değerlendir } \\
\text { (D) }\end{array}$ & Sonda & $\begin{array}{c}\text { Öğretmen öğrencinin cevabını } \\
\text { derinleştirmek istiyor. }\end{array}$ \\
\hline 4 & Öğrenci-1 & Element! & $\mathrm{C}$ & - & \\
\hline 5 & Öğretmen & $\begin{array}{c}\text { Hayır! Ne diyoruz onlara? } \\
\text { Ahmet sen söyle? }\end{array}$ & D-B & $\begin{array}{c}\text { Ret- } \\
\text { Alternatif }\end{array}$ & $\begin{array}{c}\text { Öğretmen cevabı reddediyor ve } \\
\text { doğru cevabı arıyor. }\end{array}$ \\
\hline 6 & Öğrenci-2 & Atom! & $\mathrm{C}$ & - & \\
\hline
\end{tabular}




\begin{tabular}{|c|c|c|c|c|c|}
\hline 7 & Öğretmen & $\begin{array}{l}\text { Çok güzel, "atom", } \\
\text { diyoruz. Atomla element } \\
\text { farkl1 } \mathrm{ml} \text { ? }\end{array}$ & D-B & $\begin{array}{l}\text { Kabul- } \\
\text { Sonda }\end{array}$ & $\begin{array}{l}\text { Öğretmen cevabı kabul ediyor } \\
\text { ve bir başka derinleştirme } \\
\text { sorusu yöneltiyor. }\end{array}$ \\
\hline 8 & Öğrenci-2 & Farklı Hocam... & $\mathrm{C}$ & - & - \\
\hline 9 & Öğretmen & Tamam da nasıl farklı? & D-B & Sonda & $\begin{array}{l}\text { Öğretmen cevabı kabul ediyor } \\
\text { ve bir başka derinleştirme } \\
\text { sorusu yöneltiyor. }\end{array}$ \\
\hline 10 & Öğrenci-2 & $\begin{array}{c}\text { Mesela su farklı } \\
\text { atomlardan oluşan bir } \\
\text { elementtir mesela Hocam. }\end{array}$ & $\mathrm{C}$ & - & 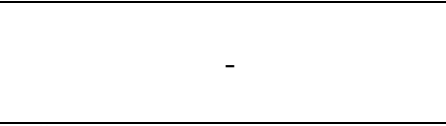 \\
\hline 11 & Öğretmen & Su bir element mi? & D-B & Ret & Öğretmen cevabı reddediyor \\
\hline 12 & Öğrenci-2 & Evet Hocam. & $\mathrm{C}$ & - & - \\
\hline 13 & Öğretmen & $\begin{array}{c}\text { Başka fikri olan var mi? } \\
\text { Yani element ve atoma } \\
\text { düzgün bir örnek verecek } \\
\text { olan? } \\
\end{array}$ & D-B & $\begin{array}{c}\text { Ret- } \\
\text { Alternatif }\end{array}$ & $\begin{array}{c}\text { Öğretmen cevabı reddediyor ve } \\
\text { doğru cevabı arıyor. }\end{array}$ \\
\hline
\end{tabular}

* Diyaloglar gerçek sınıf ortamından alınmıştır.

Her bir tablo için (Tablo 2, Tablo 3), "sıra” sütunu konuşma sıralarını, "konuşmacı" sütunu öğretmenin ve öğrencilerin “diyaloğa” katkılarını göstermektedir. "Konuşma örüntüsü” diyaloğu kimin başlattığını, başlatılmış diyaloğa kimin cevap/reaksiyon verdiğini ve verilmiş cevapların/reaksiyonların içeriğinin kimin tarafından değerlendirildiğini ya da eleştirildiğini göstermektedir. Öğretimsel aktiviteyi çevreleyen öğretmen konuşmasının söylemsel içeriği ve pedagojik açıdan ne işe yaradığı ise son iki sütunda gösterilmiştir. Her iki diyalogda da konu içeriği atomlar ve elementlerdir. Öğretmen öğrencileri ile atomlar konusu ile ilgili bir durumu konuşmaktadır. Öğretmen kapalı uçlu bir soru ile diyaloğu başlatmıştır (konuşma sırası-1). Öğrenci-1 atomun içindeki temel şeyin parçacıklar olduğunu iddia etmiştir (konuşma sırası-2). Öğretmen bu cevabı kabul etmiş ve cevabı derinleştirmek amacıyla öğrenciden parçacıkları karakterize edecek bir (bilimsel) etiket istemiştir (konuşma sırası-3). Öğretmen bu hamlesi ile daha formalize edilmiş bir dil kullanmak istediği mesajını öğrencilere vermiştir. Öğrenci-1 mevcut diyalogla diğer öğrencilere göre daha ilgili olduğundan hızlı bir şekilde "element" etiketini öğretmenin değerlendirmesine sunmuştur (konuşma sıras1-4). Öğretmen sunulan etiketi reddetmiș ve doğru bir cevap (etiket) bulmak üzere hızlıca başka bir öğrenene söz hakkı vermiştir (konuşma sırası-5). Bu anda öğretmen bir "aklımdakini bil" durumu yaratmış ve sunulan cevapla beklenilen cevabın mutlaka uyuşması yönünde bir epistemik otorite kurmuştur. Konuşma sırası-6' da da görüldügü üzere öğretmen, beklediği cevabı (atom) bir öğrenciden almıştır. Öğretmen, hemen sonrasında atom ve elementin farklı şeyler olup olmadığını öğrencilere sormuştur (konuşma sırası7). Bu soru öğretmenin sık1 ve değiştiril(e)mez bir öğretim ajandası olduğunu ve öğretimsel akış1 bu ajandanın içinde yer alan kavramlarla ya da pratiklerle ilerletmek istediğini göstermektedir. Öğrenci-2 bu iki olgunun birbirinden farklı olduğunu kısaca ifade etmiş, ancak ne bir açıklama ne de bir gerekçelendirme yapmıştır (konuşma sıras1-8). Bir sonraki hamlede öğretmen beklendik bir şekilde farklılığın nasıl ve ne yönde olduğunu açıklaması için bir talep oluşturmak üzere bir soru yöneltmiştir. Konuşma sırası-10'da öğrenci-2 suyun bir element örneği olduğunu ifade etmiştir. Hemen sonrasında öğretmen, ciddi bir biçimde "su bir element örneğidir" cevabını reddetmiş (su esasında bir bileşiktir ve farklı elementlerin kendi özelliklerini kaybettiği bir kimyasal reaksiyon sonucu oluşur) ve öğrenci-2'ye (anlamsız) cevabını revize etmesi için bir firsat daha sunmuştur (konuşma sıras1-11). Öğrenci-2 suyu bir element olarak kabul etmeye devam etmiş (konuşma sıras1-12) ve öğretmenin ilgili soruyu doğru (“...düzgün bir örnek verecek olan”) bir cevabın acilen bulunması için başka birine ya da sınıfın tamamına yöneltmesine ve "aklımdakini bil" oyununa 
devam etmesine yol açmıştır (konuşma sırası-13). Bu diyalogda öğretmen açıkça hem epistemik hem de sosyal otorite rollerini korumuştur. Öğretmen, genellikle daha formalize edilmiş bir dili ve düşünceyi öne çıkarmaya çalışmakta ve öğrenenlerin sınıf içine zorunlu olarak getirdiği çoğunlukla yanlış ya da alternatif olabilen informal dilleri ve düşünceleri yok saymıştır. Öğrenenler, bu diyalogda öğretmenin zihninden geçen kavramları bilmeye çalışan sınıf üyeleri olarak davranmış ve temel amaçlarını öğretmene doğru bir cevap vererek onu tatmin etmek ve/veya hoşnut etmek olarak belirlemişlerdir. $\mathrm{Bu}$ bağlamda paylaşılmamış otoritelerin daha fazla olumsuz öğrenen davranışına yol açabileceği söylenebilir. Öğrenenlerin alternatif akıl yürütmeleri (sadece) öğretmen tarafından değerlendirildiğinde ve reddedildiğinde, öğrenenler sınıfta müzakere edilen olgulara bilişsel katkılar sağlayamadıklarında, toplamda ise, sınıf içi süreçlere entelektüel olarak bağlanıp kendilerini bilişsel olarak yüklü ve sorumlu hissetmediklerinde beklendik bir şekilde olumsuz davranışlar gösterme eğiliminde olabileceklerdir.

Tablo* 4. Diyalog-II ve daha simetrik söylemsel güç ilişkileri

\begin{tabular}{|c|c|c|c|c|c|}
\hline 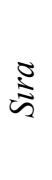 & 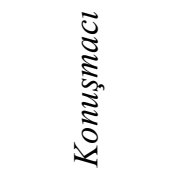 & Diyalog & $\begin{array}{l}\text { Konuşma } \\
\text { örüntüsü }\end{array}$ & $\begin{array}{l}\text { Söylemse } \\
\text { l hamle }\end{array}$ & Fonksiyon \\
\hline 1 & Öğretmen & $\begin{array}{l}\text { Evet, maddenin içinde ne } \\
\text { var çocuklar? }\end{array}$ & Başlat (B) & $\begin{array}{l}\text { Kapal1- } \\
\text { uçlu soru }\end{array}$ & $\begin{array}{l}\text { Diyalogu başlatmak için } \\
\text { öğretmenin sorduğu soru }\end{array}$ \\
\hline 2 & Öğrenci-1 & Parçacıklar var, Hocam. & Cevap al (C) & - & - \\
\hline 3 & Öğretmen & $\begin{array}{l}\text { Tamam da işte onlara ne } \\
\text { diyoruz? }\end{array}$ & $\begin{array}{l}\text { Değerlendir } \\
\text { (D) }\end{array}$ & Sonda & $\begin{array}{c}\text { Öğretmen öğrencinin cevabını } \\
\text { derinleştirmek istiyor. }\end{array}$ \\
\hline 4 & Öğrenci-1 & Element! & $\mathrm{C}$ & - & \\
\hline 5 & Öğretmen & $\begin{array}{l}\text { Hayır! Ne diyoruz onlara? } \\
\text { Ahmet sen söyle? }\end{array}$ & D-B & $\begin{array}{l}\text { Ret- } \\
\text { Alternati } \\
\quad \mathrm{f}\end{array}$ & $\begin{array}{l}\text { Öğretmen cevabı reddediyor ve } \\
\text { doğru cevabı arıyor. }\end{array}$ \\
\hline 6 & Öğrenci-2 & Atom! & $\mathrm{C}$ & - & \\
\hline 7 & Öğretmen & $\begin{array}{c}\text { Çok güzel "atom”, } \\
\text { diyoruz. Atomla element } \\
\text { farklı mı? }\end{array}$ & D-B & $\begin{array}{l}\text { Kabul- } \\
\text { Sonda }\end{array}$ & $\begin{array}{l}\text { Öğretmen cevabı kabul ediyor } \\
\text { ve bir başka derinleştirme } \\
\text { sorusu yöneltiyor. }\end{array}$ \\
\hline 8 & Öğrenci-2 & Farkl1 Hocam... & $\mathrm{C}$ & - & - \\
\hline 9 & Öğretmen & Tamam da nasıl farklı? & D-B & Sonda & $\begin{array}{c}\text { Öğretmen cevabı kabul ediyor } \\
\text { ve bir başka derinleştirme } \\
\text { sorusu yöneltiyor. }\end{array}$ \\
\hline 10 & Öğrenci-2 & $\begin{array}{c}\text { Mesela su farklı } \\
\text { atomlardan oluşan bir } \\
\text { elementtir mesela Hocam. }\end{array}$ & $\mathrm{C}$ & - & ( \\
\hline 11 & Öğretmen & Su bir element mi? & D-B & Ret & Öğretmen cevabı reddediyor. \\
\hline 12 & Öğrenci-2 & Evet Hocam. & $\mathrm{C}$ & - & - \\
\hline 13 & Öğretmen & $\begin{array}{c}\text { Arkadaşlar ne } \\
\text { diyorsunuz? Arkadaşınız } \\
\text { suya element diyor? }\end{array}$ & $\begin{array}{l}\text { T (Takip } \\
\text { sorusu) }\end{array}$ & $\begin{array}{l}\text { Değerlen } \\
\text { dirme } \\
\text { yönlendir } \\
\text { mesi }\end{array}$ & $\begin{array}{l}\text { Öğretmen diğer öğrencileri } \\
\text { verilmiş cevabı } \\
\text { değerlendirmeleri için davet } \\
\text { ediyor. }\end{array}$ \\
\hline 14 & Öğrenci-3 & Olabilir Hocam. & $\mathrm{C}$ & - & \\
\hline 15 & Öğrenci-4 & $\begin{array}{c}\text { Hocam su da } \\
\text { elementlerden oluşur } \\
\text { sonuçta. } \\
\end{array}$ & $\mathrm{C}$ & - & \\
\hline
\end{tabular}




\begin{tabular}{|c|c|c|c|c|c|}
\hline 16 & Öğretmen & $\begin{array}{l}\text { Elementlerin düzenli } \\
\text { gösterildiği bir tablo var } \\
\text { mıydı? }\end{array}$ & B & $\begin{array}{l}\text { Nötr- } \\
\text { Sonda }\end{array}$ & $\begin{array}{c}\text { Öğretmen herhangi bir } \\
\text { olumlu/olumsuz değerlendirme } \\
\text { yapmadan öğrencinin cevabını } \\
\text { derinleştirmek istiyor. }\end{array}$ \\
\hline 17 & Öğrenci-4 & $\begin{array}{l}\text { Evet Hocam. Geçen sene } \\
\text { öğrenmiştik: elementlerin } \\
\text { periyodik tablosu. }\end{array}$ & $\mathrm{C}$ & - & - \\
\hline 18 & Öğretmen & Bu tablo ne işe yarıyordu? & D-B & $\begin{array}{l}\text { Kabul- } \\
\text { sonda }\end{array}$ & $\begin{array}{l}\text { Öğretmen cevabı kabul ediyor } \\
\text { ve bir başka derinleştirme } \\
\text { sorusu yöneltiyor. }\end{array}$ \\
\hline 19 & Öğrenci-3 & $\begin{array}{l}\text { Şey Hocam... Elementleri } \\
\text { kendi içinde topluyordu. }\end{array}$ & $\mathrm{C}$ & - & \\
\hline 20 & Öğretmen & $\begin{array}{l}\text { Ne demek istedin } \\
\text { anlayamadım? }\end{array}$ & $\mathrm{T}$ & $\begin{array}{l}\text { Açıklaştı } \\
\text { rma }\end{array}$ & $\begin{array}{l}\text { Öğretmen cevabı anladı, ancak } \\
\text { diğerlerinin de anlaması için } \\
\text { cevabı verenden cevabını daha } \\
\text { açık bir dille ifade etmesini } \\
\text { istiyor. }\end{array}$ \\
\hline 21 & Öğrenci-3 & $\begin{array}{c}\text { Yani ögretmenim onları, } \\
\text { şeyleri, yani elementleri } \\
\text { benzer özelliklerine göre } \\
\text { bir araya toplamış onu } \\
\text { yapan. } \\
\end{array}$ & $\mathrm{C}$ & - & 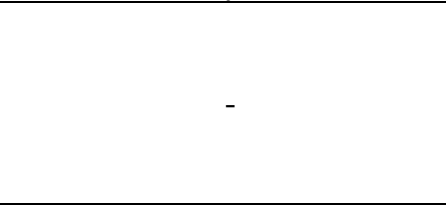 \\
\hline 22 & Öğretmen & $\begin{array}{c}\text { Tamam, ben de } \\
\text { katıliyorum sana. Peki o } \\
\text { zaman su bir elementse } \\
\text { orada var midır? } \\
\end{array}$ & D-B & $\begin{array}{l}\text { Kabul- } \\
\text { tahmin }\end{array}$ & $\begin{array}{l}\text { Öğretmen cevabı kabul ediyor } \\
\text { ve öğrencilerden tahminde } \\
\text { bulunmasını talep ediyor. }\end{array}$ \\
\hline 23 & $\begin{array}{l}\text { Öğrenciler } \\
\text { (hep bir } \\
\text { ağızdan) }\end{array}$ & Tabi vardır Hocam (?!) & $\mathrm{C}$ & - & - \\
\hline 24 & Öğretmen & $\begin{array}{c}\text { O zaman inceleyelim mi } \\
\text { periyodik tabloyu ne } \\
\text { dersiniz? Su nerede imiş } \\
\text { görelim? } \\
\end{array}$ & D-B & $\begin{array}{l}\text { Kabul- } \\
\text { maddileş } \\
\text { tirme }\end{array}$ & $\begin{array}{c}\text { Öğretmen cevabı kabul ediyor } \\
\text { ve öğrencileri gerçek verili } \\
\text { sistemi incelemeleri için } \\
\text { yönlendiriyor. } \\
\end{array}$ \\
\hline \multicolumn{6}{|c|}{ Öğrenciler hep birlikte kısa bir süre periyodik tabloda "su elementini" ararlar. } \\
\hline 25 & Öğrenci-2 & $\begin{array}{c}\text { Öğretmenim burada su } \\
\text { yok... }\end{array}$ & $\mathrm{C}$ & - & - \\
\hline 26 & Öğretmen & $\begin{array}{c}\text { Ama sen suya element } \\
\text { demiştin ve kesinlikle eğer } \\
\text { senin dediğin doğru ise } \\
\text { suyun tabloda yer alması } \\
\text { lazım. } \\
\end{array}$ & B & İzleme & $\begin{array}{l}\text { Öğretmen "kavramsal değişim" } \\
\text { için öğrencinin önceki ve anlık } \\
\text { oluşan fikrini ona hatırlatıp, } \\
\text { karşılaştırma yapmasını istiyor. }\end{array}$ \\
\hline 27 & Öğrenci-3 & $\begin{array}{l}\text { Hocam ben hatırladım. } \\
\text { Suda hidrojen ve oksijen } \\
\text { vardı. Ben onları burada } \\
\text { buldum ama su yok. }\end{array}$ & $\mathrm{C}$ & - & - \\
\hline 28 & Öğretmen & $\begin{array}{l}\text { O zaman su element } \\
\text { olmayabilir mi? }\end{array}$ & D-T & $\begin{array}{l}\text { Tahmin } \\
\text { etme }\end{array}$ & $\begin{array}{c}\text { Öğretmen cevabı kabul ediyor } \\
\text { ve öğrencilerden su ile ilgili bir } \\
\text { tahminde bulunmalarını talep } \\
\text { ediyor. }\end{array}$ \\
\hline 29 & Öğrenci-3 & $\begin{array}{l}\text { Evet Hocam o başka bir } \\
\text { şey olabilir? Olsa zaten } \\
\text { burada olurdu. }\end{array}$ & $\mathrm{C}$ & - & \\
\hline
\end{tabular}


Tablo 3 ve Tablo 4'teki temel pedagojik farklılıklar ve bunların sınıf yönetimi olgusuna yansımaları, 13. hamlenin değişimi ile başlayan ve devam ettirilen sınıf içi etkileşimlerle açıklanabilmektedir. Öğrenci-2, suyun bir element olduğunu ifade edip bu iddiasında 1srar ettiğinde (Tablo 4, konuşma sıras1-12), bir önceki diyalogda olduğu gibi öğretmen, bu ilgisiz ya da yanlış cevabı tamamen yok sayabilir ve doğru cevabın acilen bulunması için diğer öğrenenleri görevlendirebilirdi (Tablo 3, konuşma sırası 13). Ancak öğretmen, Öğrenci-2'nin bu cevabına farklı bir pedagojik hamle ile reaksiyon vermiştir. Tablo 4'te görüldügü üzere öğretmen verilen cevab1 direkt olarak değerlendirip reddetmektense diğer öğrenenlerin değerlendirmesine sunmuştur (Tablo 4, konuşma sırası-12). Öğretmen, bu hamle ile diğer öğrenenleri eşdeğerlendirmeci konumuna yükseltmiştir. Bu hamle ile öğretmen, ilk defa epistemik otoriteyi paylaşma girişiminde olmuştur. Çünkü artık suyun bir element olup olmadığı fikrini değerlendirecek ya da eleştirecek diğer sesler de duyulmaya başlanabilecektir. Devam eden konuşmalarda Öğrenci-3 ve Öğrenci-4 çeşitli cevaplar sunmuştur. Öğrenci-3, var-yok ya da evethayır biçimde düşük düzeyli ya da gerekçesiz bir değerlendirme yapmıştır (konuşma sırası-14). Öğrenci-4 ise başka bir akıl yürütme yapmış ve suyun -elementlerden oluştuğundan- bir element adayı olabileceğini ifade etmiştir (konuşma sıras1-15). Öğretmen, biri derinliksiz ve gerekçesiz diğeri ise yanlış olan iki cevabı aldıktan sonra "tarafsız kalabilme" durumunu koruyabilmiş ve bir takip sorusu ile diyaloğu devam ettirmeyi pedagojik olarak tercih etmiştir (konuşma sırası-16).

Devam eden konuşmalarda (konuşma sırası-17, 18, 19, 20 ve 21) öğretmen, öğrencilerle bir doğrulayıcı konuşma yapıyor ve elementlerin düzenli bir şekilde yer aldığı periyodik tablo olgusunu onlara onların aracılığıyla hatırlatmıştır. Konuşma sırası-22'de öğretmen, kritik bir pedagojik hamleyi gerçekleştiriyor ve öğrenenleri rasyonel bir akıl yürütme yapmaya davet ediyor: "Eğer su bir elementse mutlaka periyodik tabloda yer almalıdır." Bu rasyonel davet, bütün öğrenciler tarafından kabul görüyor ve öğretmen tüm öğrenenleri periyodik tabloda su “elementini” aramak için yönlendiriyor. Bu bağlamda, artık epistemik otorite hem öğrenenler hem öğretmen hem de dış verili sistemler hâline dönüşüyor. Çünkü öğretmen, öğrenenlerin akıl yürütmelerinin test edilmesi ya da daha makul olanı ile değiştirilmesi için maddi (verili) bir sistem üzerinden aktiviteyi sürdürme ile ilgili aldığı bir pedagojik kararı uygulamıştır. Öğrenenler, başlangıç hipotezlerini test etmek adına suyu periyodik tabloda arama girişiminde bulundurmuştur. Ancak, Öğrenci-2'nin de belirttiği üzere (konuşma sırası-25) su, elementlerin en genel tablosu olan periyodik tabloda yer almamıştır. Konuşma sırası-26'da öğretmen, hem öğrenci-2'ye hem de sınıfın diğer tüm üyelerine fikirlerini daha makul olanla revize edebilmeleri için geriye dönük bir hatırlatma yapmamıştır: öğrenenlerden önceki ve periyodik tabloyu inceledikten sonraki fikirlerini karşılaştırmalarını istememiştir. Ardından Öğrenci-3, suyun hidrojen ve oksijen elementlerinden oluştuğunu, bu iki elementin periyodik tabloda olduğunu, ancak suyun olmadığını verili bir şekilde ifade etmiştir (konuşma sırası-27). Öğretmen, bu cevabın ardından ilk kez bir entelektüel pozisyon alma ve bunu öğrenenlere hissettirme eğiliminde olmaktadır (konuşma sırası-28). Konuşma sırası29' da öğrencilerden biri, ilk kez "su bir elementtir" fikrinin doğru olamayabileceği ile ilgili bir durumu kabul edebilecekleri hakkında bir sinyal vermiştir ve argümanını -suyun esasen "başka" bir şey olduğunu- maddi-verili bir sistemden elde ettiği gözlemler aracıllğıyla güçlendirmiştir (“...olsa zaten burada olurdu”). Özetle öğretmen, öğrencilerin sınıf ortamına getirdikleri günlük dillerini ilk anda reddetmediğinde ve diyalog akışını bu sosyal dil üzerinden kurguladığında öğrenenler, öğrenme süreçlerine daha çok bağlanabilir ve bilişsel olarak kendilerini daha donanımlı hissedebilirler. Ötesinde öğretmenin ikinci diyalog akşında yaptığı özellikli hamleler, öğretimsel aktivitenin pedagojik kaderini ya da sonucunu tayin etme konusunda belirtildiği üzere gösterildiği üzere ciddi derecede etkin olabilmiştir. Öğretmen belli başlı hamleler yaparak epistemik otoritesini 
paylaşabilmiş ve diğerlerini de ortaya çıkan fikirleri eleştiren ve değerlendirebilen eş-eleştiriciler ya da eş-değerlendiriciler konumuna yükseltmiştir. Dolayısıyla Tablo-3 ve Tablo-4'te sergilenen öğretmen hamlelerinin niceliklerindeki artış, olumlu davranışların artmasına ya da olumsuz davranışların gözlemlenmesine ciddi derecede yansıyabilecektir. Desteklemek gerekirse sürekli bilimin sosyal dili ve etiketleri ile sıkı bir biçimde değerlendirilmeye maruz kalan ve çoğunlukla alternatif konuşma ve düşünme sistemleri reddedilen öğrenenler, zamanla sınıfla entelektüel bağlarını yitirecek ve bilişsel olarak donanımlı olamadıklarından dolayı olumsuz davranışlar gösterme eğiliminde olabileceklerdir. Ancak öğrenenler doğru zamanda ve bağlamda sergilenen belirli pedagojik hamlelerle eş-otoriteler hâline getirildikçe entelektüel olarak sınıftaki öğrenme olgusuna katkıda bulunma anlamında birinci dereceden sorumlu olacaklarından sınıf içi süreçlere daha derinden bağlanabilecek ve minimum düzeyde olumsuz davranış sergileme eğiliminde olabileceklerdir.

\section{Tartışma ve Sonuç}

Görüldüğü ve tartışıldığı üzere öğretmenlerin hem maddi-fiziksel kurulumu hem de öğretimsel faaliyetlerin aksiyonel yönelimlerini öğrencilerin yararına düzenlenmeleri olumlu öğretim çıktılarının sağlanması için kritik öneme sahiptir. Öğrenenler, öğretimsel faaliyetlere esaslı bir şekilde katkıda bulunabildiklerinde, öğrenilecek olguyu öğretmenle birlikte inşa eden eşgörevliler ve eş-değerlendirmeciler hâline dönüşebildiklerinde, sınıf yönetimi olgusu öğretimsel sistemden ya da akıştan elemine edilen bir olguya dönüşebilmektedir. Ayrıca, bu çalışmada da gösterilmekte olduğu gibi, öğrencilerin anlamlı ve etkili bir şekilde öğrenme faaliyetlerine katılabilmeleri öğretmenlerin sınıfın maddi kurulumunu düzenleyebilmelerinden ziyade, onların öğretimsel perspektiflerine (teorik) ve faaliyetlerine (pratik) ait bilgilerinin, becerilerinin ve pedagojik farkındalıklarının geliştirilmesine bağlıdır. Öğrenme-öğretme süreçleri ne kadar karmaşık ve soyut öğeleri, durumları ve etkileşimleri (sözel, sözel olmayan) içeriyorsa, olumsuz davranışların öğretimsel süreçlerden elemine edilmesi ya da sınıf yönetiminin tayini de o kadar kompleks bir olgudur. Delillendirildiği üzere, sınıf yönetimi olgusu, öğretimsel perspektiften ve ona sıkı sıkıya eşlik eden otorite tiplerinden ve söylemsel güç ilişkilerinden ayırt edilemez; yalıtılmış bir şekilde incelenemez. Bu bir zincir reaksiyona benzetilebilir. Öğretmenin öğretim esnasında yarattığı, meşrulaştırdığı ya da yok ettiği, öğrenenler tarafından dolaylı ya da doğrudan gözlemlenen ya da algılanan, gizil ya da açık otorite olgusu, sınıf yönetimi olgusunun ontolojik geleceğini tayin eder. Ontolojik olarak düşünüldüğünde, öğretmen direkt etkileşimler aracıllğ̆1yla, öğrenenleri birer bilici, katkıcı ve değerlendirici olarak atadığında, onlar birer epistemik ve sosyal otorite haline geleceklerdir, yani öğretmene ek olarak öğrencilerde sınıf süreçlerinde var edileceklerdir. Olgubilim dünyasında (fenomenler dünyası), bizlere görünen şeyler arasında ancak ve ancak farklılıklar olduğunda zihinsel olarak onları ayırt edebilir, kategorize edip, aralarında hiyerarşiler kurabiliriz (Marton, 1981; 1994; 2000). Bu şuna benzetilebilir: "bir şelalenin yanında uzun süre kaldığınızda, şelalenin yarattı̆̆ı ses sabitleşir ve onu duyana normalleştirilir. Çünkü şelalenin yarattığı ses artık diğer seslerin arasındadır ve farklılaşamadağ iç̧in, özel bir ses olarak algılan(a)maz" (Marton, 1981; 1994; 2000). O ses artık siradan bir sestir.

Sınıfta da otorite olgusu sürekli paylaşıldığında, otoriteler arasında hiyerarşik farklılıklar olmadığında ve bu bir süreklilik arz ettiğinde bu olgu artık sıradanlaşmıştır, sabitleşmiştir ve normalleşmiştir. Her bir üyenin epistemik ve sosyal otorite olduğu öğretimsel süreçler bütününde, ontolojik olarak otorite kavramı arayışına girmek, dolayısıyla, doğru olmayacaktır. Çünkü otorite olgusu adına farklılık ya da hiyerarşi yaratan unsur olan öğretmen (yani öğretmenin daha büyük 
bir otorite olarak diğer üyelerden farklılaşması) ona sosyo-kültürel (sözde eğitimin bir gereği olarak) olarak bahşedilmiş otoritesini paylaşarak otoriteyi yok edebilecektir. Başka bir deyişle, ögretmenin sınıfi yönetmesinin tek yolu, kendi otoritesini yok ortadan kaldırmasıdır. Çünkü nesnelerin yönetimi özneler aracılığıyla, öznelerin yönetimi ise öz-özneler aracılığıyla gerçekleşebilir (Freire, 1970). Öğretmen, başka bir deyişle, otoritesini belli başlı öğretimsel faaliyetlerle paylaştığında, sınıf yönetimi adına kendine düşen yükümlülükleri diğer üyelerle, öğrenenlerle, paylaşır. Son tahlilde, grubu öğretmen değil, grup yönetir.

\section{Öneriler}

$\mathrm{Bu}$ bağlamda eğitimcilerin kendilerine sorması gereken en önemli sorulardan biri, öğretmenlerin bu çalışmanın teorik perspektifini de karakterize eden ve karşılıklı belirleyici bir şekilde çalışan pedagojik perspektifler, otorite tipleri ve söylemsel güç ilişkileri olgularına ait bir kavramsallaştırmalarının ve algılarının varlığı-yokluğu ve derecesidir. Genel itibariyle öğretmenlerin bu tipte bir farkındalığa sahip olduğu söylenemez (Clandinin ve Connelly, 1995; Cochran-Smith ve Zeichner, 2005; Cochran-Smith, 2006). Dolayısıyla kasitlı ve istendik bir şekilde kurgulanmış, öğretmenlerin pedagojik perspektiflerine temas eden, kaliteli bir şekilde planlanmış ve uygulanmış mesleki gelişim programlarının önemli bir parçası olarak sınıf yönetimi eğitimi, katılımcı öğretmenlerin bu olgulara ait kavramsallaştırmalarını, farkındalıklarını ve pratiklerini geliştirebilir (Cochran-Smith, 2001, 2003, 2004, 2005, 2006). Bu bağlamda bir öğretmen, öğretimsel faaliyetler (ör., sınıf yönetimi olgusu) ile ilgili var olan pedagojik bilgisine yeni bilgiler ekleyebilir, becerilerini geliştirebilir, başka bir öğretimsel yönelimi benimseyip ona karşı olumlu bir tutum geliştirebilir. Ancak bu tipte nicel artışlar, mesleki bir nitel dönüşüm ve değişim için yeterli ol(a)mamaktadır. Bu bağlamda öğretmenin öğretimsel faaliyetleri düzenlemesi uzun süreçler sonucunda gerçekleşen ve daha derin, nitel değişim ve dönüşümleri gerektiren bir olgudur (Cochran-Smith, 2001, 2003, 2004, 2005, 2006). Daha da önemlisi öğretmenlerin olumlu öğrenen davranışlarını karakterize eden öğrenen-merkezli bir bağlamı benimsemesi ve bu öğretimsel faaliyetlerini rutin pratikler hâline getirmeleri, bu süreçlerde aksayan durumlar üzerine reflektif pratikler yapmaları gerekmektedir (Schon, 1983; 1987). Başka bir deyişle öğretmenler, video-temelli sınıf içi pratiklerin yeniden ve sürekli gözden geçirilmesi yoluyla ve kendi pratiklerine öz-yansıtma yaparak yukarıda bahsi geçen karmaşık ilişkiler ve örüntüler bütününü çözümleyebilir ve rutin pratikler hâline getirebilirler (Calderhead 1981; Nilsson ve Vikström 2015). Bu bağlamda bu çalışma sonucunda araştırmacıların sınıf yönetimi olgusuna ilişkin öğretmen gelişimi ve değişimi adına maddi önerileri şunlardır:

- Öğretmenlerin yukarıda sunulan sinıf yönetimi olgusuna ait temel kavramsallaştırmaları, farkındalıkları ve pratikleri edinmesi zor, çok yönlü ve karmaşık bir süreçtir, bu hem eğitimciler hem de bu tipte bir sürece girişen ögretmenlerce kabul edilmelidir.

- Sınıf yönetiminin iyileştirilmesinde, öğretimsel faaliyetlerin düzenlenmesi ile ilgili bilgi ve beceriler, "öğretmen öğrenmesinin ve "öğretmen mesleki gelişiminin içinde yer aldĭ̆gl, uzun bir süreçtir; anlık çabalar, tekli uygulamalar; bu süreci desteklemek yerine geriye götürmektedir.

- Öğrenenlerin anlamlı öğrenmesi için kullanılan bir takım öğrenen-merkezli süreçler, ögretmenlerin anlamlı ögrenmesi ve sınıf yönetimi olgusu ile ilgili gelişimi için de bir ziplama tahtası oluşturabilir.

- Sınıf yönetimi olgusu bağlamında öğretimsel süreçlerin iyileştirilmesinin en iyi yollarından biri; bu sürecin sunum-seminer biçiminde bir bilgi aktarımı değil, "öğretmenler adına" 
ancak "ögretmenlerle birlikte" olan bilimsel araştırmalar yoluyla ilerletilmesi ve geliştirilmesidir.

\section{Referanslar}

Åkerlind, G. S. (2003). Growing and developing as a university teacher-variation in meaning. Studies in Higher Education, 28, 375-390.

Åkerlind, G. S. (2004) A new dimension to understanding university teaching. Teaching in Higher Education, 9, 363-376.

Åkerlind, G. S. (2007). Constraints on academics' potential for developing as a teacher. Studies in Higher Education, 32(1), 21-37.

Åkerlind, G. S. (2008). A phenomenographic approach to developing academics' understanding of the nature of teaching and learning. Teaching in Higher Education, 13(6), 633-644.

Alexander, R.J. (2001). Culture and pedagogy: International comparisons in primary education. Oxford: Blackwell.

Alexander, R.J. (2006). Towards dialogic teaching: Rethinking classroom talk. New York, NY: Dialogos.

Bakhtin, M. M. (1934). Discourse in the novel. The dialogic imagination: four essays. Trans. Michael Holquist \& Caryl Emerson. Austin: University of Texas.

Bakhtin, M. M. (1986). Speech genres \& other late essays (Caryl Emerson and Michael Holquist, Ed. and Vern W. McGee, trans). Austin: University of Texas Press.

Ball, D. L., \& Cohen, D. K. (1999). Developing practice, developing practitioners: Toward a practice-based theory of professional education. In L. Darling-Hammond \& G. Sykes (Eds.), Teaching as the learning profession: handbook of policy and practice (1st ed. ed., pp. 3-32). San Francisco, Calif.: Jossey Bass Publishers.

Baer, J., \& Kaufman, J. C. (2005). Bridging generality and specificity: The Amusement Park Theoretical (APT) model of creativity. Roeper Review, 27, 158-163.

Baker, J. A., Clark, T. P., Maier, K. S., \& Viger, S. (2008). The differential influence of instructional context on the academic engagement of students with behavior problems. Teaching and Teacher Education, 24, 1876-1883.

Başar, H. (1999). Sınıf Yönetimi. Ankara: Milli Eğitim Bakanlığı Yayınları No: 3390. Celep, C. (2002). Sınıf Yönetimi ve Disiplini. Ankara: Anı Yayıncılık.

Baumanin, J.F. (1992). Organizing and Managing a whole Language Classroom. Reading Research and Instruction, 31(3), 1-14.

Becker, W. C., \& Gersten, R. (1982) A follow-up of follow through: Meta-analysis of the later effects of the Direct Instruction Model. American Educational Research Journal, 19, 7593.

Becker, H. J., \& M. M. Riel (2000). Teacher Professional Engagement and Constructivist Compatible Computer Use. Irvine, CA: University of California, Irvine and University of Minnesota, Center for Research on Information Technology and Organizations.

Berry, M. (1981). Systemic linguistics and discourse analysis: A multi-layered approach to exchange structure. In Studies in discourse analysis, ed. M. Coulthard and M. Montgomery, 120-45. London: Routledge and Kegan Paul.

Berland, L. K., \& Hammer, D. (2012). Framing for scientific argumentation. Journal of Research in Science Teaching, 49(1), 68-94.

Bloom, L.A., Perlmutter, J \& Burrell, L., (1999). Applying Constructivism to Inclusive 
Classrooms. Intervention in School and Clinic (ISC), 34(3), 132-136.

Bolhuis, S., \& M. J. M. Voeten (2004). Teachers' Conceptions of Student Learning and Own Learning. Teachers and Teaching: Theory and Practice, 10, 77-98.

Bradshaw, C. P., Bottiani, J., Osher, D., \& Sugai, G. (2014). Integrating positive behavioral interventions and supports (PBIS) and social emotional learning. In M. D. Weist, N. A. Lever, C. P. Bradshaw, \& J. Owens (Eds.), Handbook of school mental.

Brown, D. \& Clement, J. (1991). Classroom teaching experiments in mechanics. In R. Duit, F. Goldberg \& H. Niedderer (Eds.), Research in physics learning: theoretical and empirical studies. Kiel, Germany: IPN

Brookhart, S. M. \& Freeman, D. J., (1992). Characteristics of entering student teachers. Review of Educational Research, 62, 1, 37-60.

Brophy, J. (2006). History of research on classroom management. In C. M. Evertson \& C. S. Weinstein (Eds.), Handbook of classroom management: Research, practice, and contemporary issues (pp. 17- 43). Mahwah, NJ: Lawrence Erlbaum Associates.

Brophy, J. (1999). Perspectives of classroom management: Yesterday, today and tomorrow. In H. Freiberg (Ed.), Beyond behaviorism: changing the classroom management paradigm, 43-56. Boston: Allyn and Bacon.

Calderhead, J. (1981). Stimulated recall: A method for research on teaching. British Journal of Educational Psychology, 51, 211-217.

Candela, A. (2005). Students', participation as co-authoring of school institutional practices. Culture and Psychology, 11, 321-37.

Charles, C. M. (1996). Building classroom discipline (5. Bask1) White Plains, NY: Longman Publishers.

Cheng, Y.C., \& Tam, W.M. (2007). School effectiveness and improvement in Asia: Three waves, nine trends and challenges. In T. Townsend, B. Avalos, B. Caldwell, Y.C. Cheng, B. Fleisch, L. Moos, et al. (Eds.), International handbook on school effectiveness and improvement (pp. 245-268). Dordrecht, The Netherlands: Springer.

Cheng, Y.C., \& Mok, M.M.C. (2007). School-based management and paradigm shifts in education: An empirical study. International Journal of Educational Management, 21(6), 517-542.

Cheng,Y.C. (2005). Globalization and educational reforms in Hong Kong: Paradigm shift. In J. Zaida, K. Freeman, M. Geo-JaJa, S. Majhanovich, V. Rust, \& R. Zajda (Eds.), The international handbook on globalization and education policy research (pp. 165-187). Dordrecht, The Netherlands: Springer.

Cheng, Y.C., Mok, M.M.C., \& Chow, K.W. (2003). Organization and management of education in the Asia-Pacific Region: Development, reform, and growth. In J. Keeves \& R. Watanabe (Eds.), The handbook on educational research in the Asia-Pacific Region (Section 6, pp. 915-930). Dordrecht, The Netherlands: Kluwer Academic Publishers.

Cheng, Y. C. \& Townsend, T. (2000). Educational change and development in the AsiaPacific region: Trends and issues. In T. Townsend \& Y. C. Cheng (Eds.), Educational change and development in the Asia-Pacific region: Challenges for the future (pp. 317-344). Lisse, The Netherlands: Swets \& Zeitlinger.

Clandinin, D. J. \& Connelly, F. M. (Eds.) (1995). Teachers' professional knowledge landscapes. New York: Teachers College Press.

Cochran-Smith, M., \& K. Zeichner. (2005). Studying teacher education: The report of the AERA panel on research and teacher education. Mahwah, NJ: Erlbaum.

Cochran-Smith, M. (2001). The outcomes question in teacher education. Teaching \& Teacher 
Education, 17(5), 527-546.

Cochran-Smith, M. (2003). Learning and unlearning: The education of teacher educators.

Teaching and Teacher Education, 19, 5-28.

Cochran-Smith, M. (2004). Taking stock in 2004: Teacher education in dangerous times. Journal of Teacher Education, 55(1), 3-7.

Cochran-Smith, M. (2005). Teacher educators as researchers: Multiple perspectives. Teaching and Teacher Education, 21(2), 219-225.

Cochran-Smith, M. (2006). Policy, practice, and politics in teacher education. Thousand Oaks, CA: Corwin Press.

Cornelius-White, J. (2007). Learner-Centered Teacher-Students Relationships Are Effective: A Meta-Analysis. Review of Educational Research, 77, 113-143.

Corbett, D., \& Wilson, B. (2002). What urban students say about good teaching. Educational Leadership, 60, 18-22.

Cornelius-White, J. H. D., \& Harbaugh, A. P. (2009). Learner-centered insrrucrion: Building relationships for student success. Thousand Oaks, CA: Sage.

Good, T. L., \& Brophy, J. E. (2003). Looking in classrooms (9th ed.). Boston: Allyn and Bacon Bartlett, A. 1994. Implications of whole language for classroom management. Action in Tacher Education, 16, 65-74.

Crone, D. A., Hawken, L. S., \& Horner, R. H., (2010). Responding to problem behavior in schools: The Behavior Education Program (2nd Ed.) New York: Guilford.

Crone, D. H., \& Horner, R. H. (2003). Building positive behavior support systems in schools: Functional behavioral assessment. New York: Guilford.

Dabbagh, N., \& Bannan-Ritland, B. (2005). Online learning: Concepts, strategies, and applications. Upper Saddle River, New Jersey: Pearson Prentice Hall.

DeVries, R., \& B. Zan. (1994). Moral classroom, moral children: Creating a constructivist atmosphere in early education. New York: Teachers College Press.

Dollard, N., \& Christensen, L., (1996). Constructive classroom management. Focus on Exceptional Children, 29 (2), 1-24.

Doyle, W. (1986). Classroom organization and management. In M. Wittrock (Ed.), Handbook of Research on Teaching (3rd ed., pp. 392-431). New York: Macmillan.

Downey, D., \& Pribesh, S. (2004). When race matters: Teachers' evaluations of students' classroom behavior. Sociology of Education, 77(4), 267-282.

Duke, D. (Ed.). (1979). Classroom management: The 78th yearbook of the National Society for the Study of Education, Part II. Chicago: University of Chicago Press.

Edmund T. Emmer \& Laura M. Stough (2001). Classroom Management: A Critical Part of Educational Psychology, With Implications for Teacher Education, Educational Psychologist, 36 (2), 103-112.

Emmer, E., \& Sabornie, E. J. (2014). Handbook of classroom management. Routledge.

Evertson, C., \& Harris, A. (1992). What we know about managing classrooms. Educational Leadership, 74-78.

Fraser, C., Kennedy, A., Reid, L., \& Mckinney, S. (2007). Teachers' continuing Professional development: Contested concepts, understandings and models. Professional Development in Education, 33, 153-169.

Freiberg JH \& Lamb SM (2009). Dimensions of person-centered classroom management, Theory Into Practice, 48, 99-105.

Freiberg, H. J., \& Lapointe, J. M. (2006). Research-based programs for preventing and solving discipline problems. In C. M. Evertson \& C. S. Weinstein (Eds.), Handbook of classroom 
management: Research, practice, and contemporary issues (pp. 735-786). Mahwah, NJ: Erlbaum.

Freiberg, H. J., \& Huang, S. (1994). Study 2.4: Longitudinal study of the life-cycle of improving schools: Final report. Philadelphia: National Center on Education in the Inner Cities, Temple University.

Freiberg, H. J. (Ed.). (1999a). Beyond behaviorism: Changing the classroom management paradigm. Boston: Allyn \& Bacon.

Freiberg, H. J. (Ed.). (1999b). School climate: Measuring, improving, and sustaining healthy learning environments. London: Falmer.

Freire, P. (1970). Pedagogy of the oppressed (M. Berman Ramos, Trans.). New York: Herder $\&$ Herder.

Glasser, W. (1998). Choice theory: A new psychology of personal freedom. New York, NY: Harper.

Glasser, W. (1969). Schools without failure. New York: Harper \& Row. Glasscr, W. (1986). Conlrol Iheory in Ilie classroom. New York: Harper \& Row.

Gopinathan, S. \& Ho, W. K. (2000). Educational change and development in Singapore. In Townsend, T. \& Cheng, Y.C. (2000) (eds.), Educational change and development in the Asia-Pacific Region: Challenges for the future (pp. 163-184) Lisse, The Netherlands: Swets and Zeilinger Publishers.

Guskey, T. R. (1988). Teacher efficacy, self-concept, and attitudes toward the implementation of instructional innovation. Teaching and Teacher Education, 4, 63-69.

Gündüz, H. B. (2004), Eğitim Okul ve Sınıf Yönetimi. Sınıf Yönetimi Ankara: Asil Yayıncılık.

Hoban, G. (2002). Teacher learning for educational change. Buckingham, UK: Open University Press.

Jackson, P. (1968). Life in classrooms. New York: Holt, Rinehart \& Winston.

Jeremy S \& Alex H (2001) The Differential Effects of Teacher Approval and Disapproval in Junior and Infant Classrooms, Educational Psychology in Practice, 17(2), 157-167.

Jones, V. F. \& Jones, L.S. (1984). Comprehensive Classroom Management. Boston: Allyn and Bacon.

Jones, V. (1996). Classroom management. In J. Sikula (Ed.), Handbook of research on teacher education (2nd ed., pp. 503-521). New York: Simon \& Schuster.

Jussim, L., \& Harber, K. D. (2005). Teacher expectations and self-fulfilling prophecies: Knows and unknown, resolved and unresolved controversies. Personality and Social Psychology Review. 9(2), 131-155.

Kim, Y. H. (2000). Recent changes and developments in Korean school education. In T. Townsend \& Y. C. Cheng (Eds.), Educational change and development in the Asia-Pacific region: Challenges for the future (pp. 83-106). Lisse, The Netherlands: Swets \& Zeitlinger.

Ko, P.Y., \& Marton, F. (2004). Variation and the secret of the virtuoso. In F. Marton\&A.B.M.

Tsui (Eds.), Classroom discourse and the space of learning (pp. 43-62). Mahweh, NJ: Lawrence Erlbaum Associates.

Kounin, J. S. (1970). Discipline and group management in classrooms. New York: Holt, Rinehart \& Winston.

Kunter, M., \& Baumert, J. (2006). Linking TIMSS to research on learning and instruction: a re-analysis of the German TIMSS and TIMSS video data. In S. J. Howie, \& T. Plomp (Eds.), Learning mathematics and science: Lessons learned from TIMSS (pp. 335e351). Leiden: Routledge Falmer.

Kunter, M., Baumert, J. R., \& Koller, O. (2007). Effective Classroom Management and the 
Development of Subject-Related Interest. Learning and Instruction, 17, 494-509.

Landrum, T.M., \& Kauffmann, J. (2006). Behavioural approaches to classroom management.

In C.M. Evertson \& C.S. Weinstein (Eds.), Handbook of classroom management: Research, practice, and contemporary issues (pp. 47-72). Mahwah: Lawrence Erlbaum Associates.

Langdon, C. A. (1996) The third Phi Delta Kappa poll of teachers' attitudes toward the public schools, Phi Delta Kappan, 78, 3, 244-250.

Lave, J. \& Wenger, E. (1991). Situated learning: Legitimate peripheral participation. Cambridge: Cambridge University Press.

Leach, J. T., \& Scott, P. H. (2002). Designing and evaluating science teaching sequences: an approach drawing upon the concept of learning demand and a social constructivist perspective on learning. Studies in Science Education, 38, 115-142.

Lemke, J. L. (1990). Talking science: language, learning and values. Norwoord, NJ: Ablex.

Lefstein, A. (2008). Changing classroom practice through the English National Literacy

Strategy: A micro-interactional perspective. American Educational Research Journal 45, 701-37.

Lemke, J.L. (1990). Talking science: Language, learning and values. Norwood, NJ: Ablex.

Lewis, R. (1999). Teachers coping with the stress of classroom discipline, Social Psychology of Education, 3, 155-171.

Lin, A.M.Y. (2007). What's the use of 'triadic dialogue'? Activity theory, conversation analysis and analysis of pedagogical practices. Pedagogies, 2,77-94.

Lyle, S. (2008). Dialogic teaching: Discussing theoretical contexts and reviewing evidence from classroom practice. Language and Education: An International Journal, 22, 222-40.

MacBeath, J. (2007). Improving school effectiveness: Retrospective and Prospective. In T. Townsend (Ed.), International Handbook of School Effectiveness and Improvement (pp. 57-74). Dordrecht, Netherlands: Springer.

Marton, F. (1981). Phenomenography: Describing conceptions of the world around us. Instructional Science, 10, 177-200.

Marton, F. (1994). On the structure of awareness. In J. Bowden \& E. Walsh (Eds.), Phenomenographic research: Variations in method: The Warburton symposium (pp. 89100). Melbourne: RMIT.

Marton, F. (2000). The structure of awareness. In J.A. Bowden \& E. Walsh (Eds.), Phenomenography (pp. 102-116). Melbourne: RMIT.

McDermott, L.\& Somers, M. (1991). Building a research base for curriculum development: an example from mechanics. In F. Goldberg \& H. Niedderer (Eds.), Research in physics learning: theoretical and empirical studies. Kiel, Germany: IPN.

Mameli, C., \& Molinari, L. (2013). Interactive micro-processes in classroom discourse: turning points and emergent meanings, Research Papers in Education, 28(2), 196-211.

Martin, S. (2004). Finding a balance: impact of classroom management conceptions on developing teacher practice. Teaching and Teacher Education, 20, 405-422.

Marzano, R.J., Marzano, J.S., \& Pickering, D.J. (2003). Classroom management that works: Research based strategies for every teacher. Alexandria, VA: ASCD.

Mclntyre, T., \& Battle, J. (1998). The traits of "good teachers" as identified by AfricanAmerican and white students with emotional and/or behavioral disorders. Behavioral Disorders, 23, 134-142.

Meirink, J. A., P. C. Meijer, N. Verloop, \& T. C. M. Bergen (2009). Understanding Teacher Learning in Secondary Education: The Relations of Teacher Activities to Changed Beliefs about Teaching and Learning. Teaching and Teacher Education, 25, 89-100. 
Mohandas, R., Meng, H. W., \& Keeves, J. P. (2003). Evaluation and accountability in Asian and Pacific countries. In J. P. Keeves \& R. Watanabe (Eds.), International handbook of educational research in the Asia-Pacific region (pp. 107-122). The Netherlands: Kluwer Academic Publishers.

Mortimer, E., \& Scott, P. (2003). Meaning making in secondary science classrooms. Maidenhead, England: Open University Press.

Mortimer, E. F., Scott, P., \& El-Hani, C. (2012). The Heterogeneity of Discourse in Science Classrooms: The Conceptual Profile Approach. In Fraser, B. J., Tobin, K. G., \& McRobbie, C. J. (2012). International handbook of science education (Part one). Springer Dordrecht Heidelberg: London, New York. (pp. 231-246).

Murphy, P. K., Delli, L. A. M., \& Edwards, M. N. (2004). The good teacher and good teaching: Comparing beliefs of second-grade students, preservice teachers, and inservice teachers. Journal of Experimental Education, 72, 69-92

Myhill, D. (2006). Talk, talk, talk: Teaching and learning in whole class discourse. Research Papers in Education, 21,19-41.

Nelson, J. R., Johnson, A., \& Marchand-Martel la, N. (1996). Effects of direct instruction, cooperative learning, and independent learning practices on the classroom behavior of students with behavioral disorders: A comparative analysis. Journal of Emotional and Behavioral Disorders, 4, 53-63.

Nilsson, P., \& Vikström, A. (2015). Making PCK explicit-capturing science teachers' pedagogical content knowledge (PCK) in the science classroom. International Journal of Science Education, 37(17), 2836-2857.

Ornstein A.C. \& Lasley, T. J. (2000). Strategies for effective teaching. Boston: McGraw Hill.

Pefianco, E. C., Curtis, D., \& Keeves, J. P. (2003). Learning across the adult lifespan. In J. P.

Keeves \& R. Watanabe (Eds.), International handbook of educational research in the Asia-

Pacific region (pp. 305-320). The Netherlands: Kluwer Academic Publishers.

Pajares, M. F. (1992). Teachers' Beliefs and Educational Research: Cleaning Up a Messy Construct. Review of Educational Research, 62(3), 307-332.

Peterson, C. C. (2003). Lifespan human development. In J. P. Keeves \& R. Watanabe (Eds.), International handbook of educational research in the Asia-Pacific region (pp. 379- 394). The Netherlands: Kluwer Academic Publishers.

Rajput, J. S. (2001). Reforms in school education in India. Plenary speech presented at the International Forum on Educational reforms in the Asia-Pacific Region "Globalization, Localization, and Individualization for the Future", HKSAR, China

Richardson, V. (1996). The Role of Attitudes and Beliefs in Learning to Teach. In Handbook of Research in Teacher Education, edited by J. Sikula, 102-119. New York, NY: Macmillan.

Robinson, S. L., \& Griesemer, S. M. R. (2006) Helping individual students with problem behavior. In C. M. Evertson \& C. S. Weinstein (Eds.), Handbook of classroom management: Research, practice, and contemporary issues (pp. 787-802). Mahwah, NJ: Lawrence Erlbaum Associates.

Rogers, C. \& Freiberg, H.J. (1994) Freedom to learn. 3rd ed. New York: Macmillan Publishing.

Romi, S., Lewis, R., \& Katz, Y. (2009). Student responsibility and classroom discipline in Australia, China and Israel. Compare, 39, 439-452.

Rosenthal, R., \& Jacobson, L. (2000). Teacher expectations for the disadvantaged. In P., K.Smith, \& A.D. Pellegrini (Eds.), Psychology of Education: major themes (pp. 286- 
291). Routledgefalmer: London.

Schon, D. (1983). The reflective practioner: How professionals think in action. New York: Basic Books.

Schon, D. A. (1987). Educating the reflective practitioner: Toward a new design for teaching and learning in the professions. San Francisco: Jossey-Bass.

Scott, P.H. (1997). Teaching and learning science concepts in the classroom: talking a path from spontaneous to scientific knowledge. In: Linguagem, cultura e cognicao reflexoes para o ensino de ciencias, Belo Horizonte, Brazil: Faculdade de Educacao da UFMG. Scott,

P.H. (1998). Teacher talk and meaning making in science classrooms: A Vygotskian analysis and review. Studies in Science Education, 32, 45-80.

Shechtman, Z., \& Leichtentritt, J. (2004). Affective Teaching: A Method to Enhance Classroom Management. European Journal of Teacher Education, 27, 323-333.

Sanford, J.P., \& Emmer, E. T. (1988). Understanding Classroom Management: Anobservationguide. Boston: Allyn and Bacon.

Soysal, Y., \& S. Radmard, S. (2018). Social negotiations of meanings and changes in the beliefs of prospective teachers: A vygotskian perspective, Educational Studies, 44(1), 57-80.

Soysal, Y., \& S. Radmard, S. (2017a). Sosyal Oluşturmacı Öğretimin Öğretmen Adaylarının Öğrenme ve Öğretmeye Yönelik İnançlarına ve Sınıf içi Uygulamalarına Etkisinin İncelenmesi. Illkögretim Online, 16(4), 1505-1531.

Soysal, Y., \& S. Radmard, S. (2017b). An exploration of Turkish teachers' attributions to barriers faced within learner-centred teaching, Educational Studies, 43(2),186-209.

Soysal, Y., \& Tanık, H. (2017). Akademisyenlerin Öğretimsel Bariyerlere Yönelik Atıflarının

Pedagojik-Epistemolojik İnanç Sistemleri Bağlamında İncelenmesi. Yüksekögrretim ve Bilim Dergisi. 7(2), 333-352.

Stough, L. (2006). The place of classroom management and standards in teacher education. In C.M. Evertson \& C.S. Weinstein (Eds.), Handbook of classroom management: Research, practice, and contemporary issues (pp. 909-924). Mahwah: Lawrence Erlbaum Associates.

Tang, X., \& Wu X. (2000). Educational change and development in the People's Republic of China: Challenges for the future. In T. Townsend \& Y. C. Cheng (Eds.), Educational change and development in the Asia-Pacific region: Challenges for the future (pp. 133162). Lisse, The Netherlands: Swets \& Zeitlinger.

Thomas, J. A. (1998). On becoming a good teacher: Reflective practice with regard to children's voices. Journal of Teacher Education, 49, 372-380.

Viennot, L. \& Rainson, S. (1999). Design and evaluation of a research based teaching sequence: the superposition of electric fields. International Journal of Science Education, 21(1), 1-16.

Wall, C. R. G. (2016). From Student to Teacher: Changes in Preservice Teacher Educational Beliefs Throughout the Learning-to-Teach Journey. Teacher Development 20(3), 364-379.

Weissberg, R.P., Kumpfer, K.L., \& Seligman, M.E.P. (2003). Prevention that works for children and youth: An introduction. American Psychologist, 58(6/7), 425-432. 